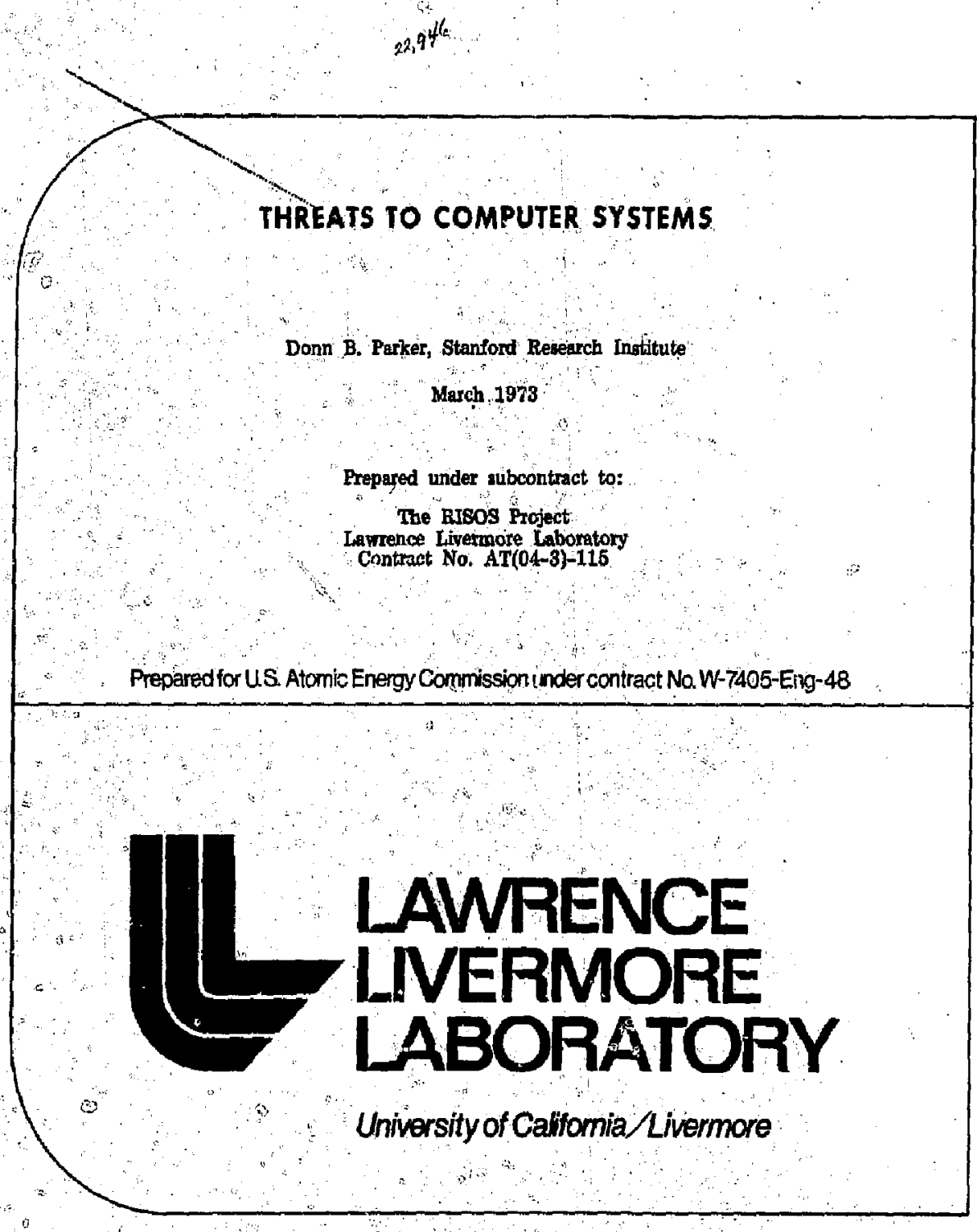

The RISOS Project is sponsored by the Advanced Resiearch Projects Agency of the Departinent of Defense

under ARPA Orde) No. 2166 ,

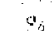




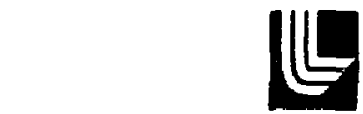

LAWRENCE UNEFIMORE LABORATOAY

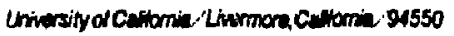

UCRL-13579

\section{THREATS TO COMPUTER SYSTEMS}

Domn B. Parker, Stanford Reweych Instilule

MS. dalc: Alareh 1073

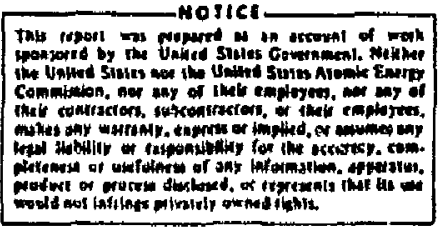

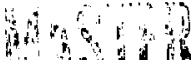

Hita 
CONTEMTS

LIST of ILLUSHatrons ................... . . . v

LIST OF TABLES ..................... . . v

PREFACE ......................... vi vi

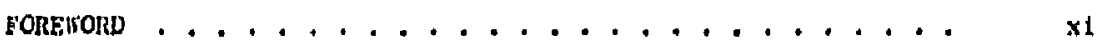

I CONTRACT FULFILLAEAT AND CONCLUSIONS . . . . . . . . 1

11 gip IRICAL approach to tireat aNaLYS IS .......... 5

III UNAUTHORIZED ACT CASE MISTORIES DATA BASE $\ldots \ldots \ldots$

Iv SURHARi of MULTIACCESS SYSTEM CASES ........... 13

y MODELS OF THREATS TO COAPUTER SYSTEMLS . . . . . . . . 27

VI REACTION AND CURREST POSITION OF COAPUTER MANUFACTURERS

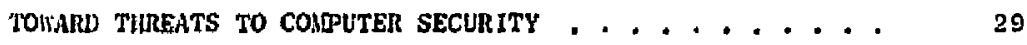

REFERENCES ....................... 33

APPENDICES

A REPORTS ON COMPUTER aLANUFACTURES VISITED . . . . . 37

B REPORTS OX RESEARCI AND SERVICE ORGANIZATIONS

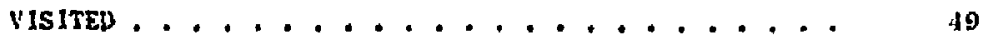

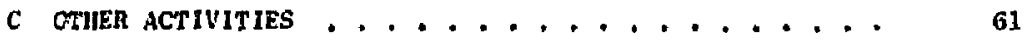

D QUESTIONNAIRE FOR DOCUAENTIKG COMPUTER-RELATED

INCIDEATS ......................... 71

E pRoJect pRoGRESS REPORT . . . . . . . . . . . . 97

y 38 ctSE HISTORIES . . . . . . . . . . . 103

G CASE IIISTORIES INYOLVING AULTIACCESS COAPUTER SYSTENS 
1 Threat Analysis Methodology. . . . . . . . . . . 6

2 Frequency Distribution of Inciclents. . . . . . . . . 8

3 Roles Played by Computers. . . . . . . . ....... 18

4 Sequential Floy Diagran Mlode: of an Incident........ 20

LIST OF TABLES

1 Cases by Year and Type . . . . . . . . . . . . . 9

2 Conceptual dutline slodel of an Incident. . . . . . . . 21 


\section{PREFACE}

As part of its continuing interest in the problem of how to improve computer security, the Advanced Research Projects Agency of the Department of Defense has funded a project, now under way at the University of California's Lawrence Livermore Laboratory, involving ways to measure, test, and evaluate the actual security of data stored in a computer system. This project, called RISOS (for Researsh in Secured operating Systems), has, as its name Indicates, a primary interest in finding out how operating systems can be made more secure. The focus of the projert is on software security is opposed to physical security. Its goal is to develop detailed security guidelines that will be of value to both system design and system operation personnel.

One aspect of the RISOs project is that it will perform not only applied research but will also test and evaluate the security of selected computer systems, as spectfied by the Depariment of Defense. The orienta$t$ ton of these test efforts is one of close collaboration between RISOS personnel and the proprietors of host computers.

The largest representation of personnel in the Risos group is systems progranmers, but other disciplines are present as well. In addition to programming, systoms analysis, and software research, the activities of the group include statigtical analyais, modeling, and hardwaxe analysis. The RISOs group is now in the process of developing and testing a series of special programs that $w 11$ assist in assessing a system's $11 \mathrm{mits}$ and capabilitios in order to obtain an jdea of its security status. These test ing programs have applicability to many types of systems in view of the amount of commonality that the group has abserved between operating systems. 
At the start of the RISOS project it quickly became apparent that one effective way to find those modules of operating systems that affect security was to examine a "historical" record of the ways security has been compromised--whether accidentally or deliberately. But what was rapidly discovered was that, owing to security precautions themselves, such a record would be almost impossible to obtain from either industry or government confidential records. The only alternative, then, was to create this record through a systematic search of public-domain information and from the leads that following up these reports might pregent. An opportunity to conduct just such a study presented itself in the form of a proposal to the RISOS project from Stanford Research Institute. The proposal was accepted and the present report sums up the results of that subcontract.

In all, 129 cases of various types of computer-related losses, injuries, and damages have been described, analyzed, or summarized in this report. As may have been expected, considering the great increase in aqareness of computers as well as the actual amount of information stored in this medium, the accurrence of such incidents has risen shaxply in the last few years. Computer-related crime runs the gamut from someone at tempting to administer the coup-de-grace to a computerm-several shots were fired at one, denting a cabinet but leaving the machine itself undamaged--to the actual piece-by-piece theft of a complete computer. Between these extremes are the really sophisticated security threats that involve the compromise or subversion of programs and operating systems. 
The survey effort embodied in this report has been of considerable use to the Risos project in providing both a base of reference for investigating system security problems and a methodology for the study and analysis of future incidents.

--Robert P. Abbott

Principal Investigator

RIsos Project

Lawrence Livermore Laboratory

University of Californta

Livermore, California 


\section{FOREWORD}

Computer-related crime $e^{*}$ is a term frequently used to describe the subject of this study. This impact term might be more accurately replaced by the following description: computer-related incidents of intentionally caused or threatened losses, injuries, and damage. This descripticn covers the entire spectrum from crimes as defined by legislative action to unauthorized acts and disputed incidents. Such events will be referred to in this report as acts, cases, or incidents as applicable.

\footnotetext{
*Numbered references are listed at the end of the main body of the report.
} 


\section{CONTRACT FULFILLMERT AND CONCLUSIONS}

This report describes the results of interdisciplinary investigation and analysis of threats to the security of multiaccess, on-line computer systems and the development of a methodology for future similar investigations and analyses. The research was conducted in the Information Science Laboratory of SRI's Information Science and Engineering Divisiou. The ma.jor activities included visits to comnuter manufacturers and computer service organizations; office and field investigation of incidents; attendance at conferences and a workshop; and meetings with the kISOS Project staff. One progress report, 11 visit reports, two oral presentations, two questionnaire case reports, and a case investigation manual were prepared and delivered to Project RISOS.

The reports on visits to computer manufacturers are included in the appendices and summarized in this re:urt. The other reports on visits to MIT, Walpole Prison EDP Training Program, Tymshare, TRW systems, Credit Data, Rohr Industries, and Jerry Schneider (a computer crime perpetrator) are also included in the appendices.

A methodology that SRI developed for carrying out investigations is embodied in another document, Manual for Investigation of Computer-Related Incidents of Intentional1y Caused Losses, 1 njuries, and Damage, and in the questionnaire designed to document cases foi further analysis (see Appendix D). This methodology is based on experience in investigation of 46 of 129 reported cases over the past seven years. Two cases were investigated using the formalized methodology and are reported in questionnaire form (see the appendix of the Investigation manual). A bibliography of 280 documents has also been separately transmitted to Projeat RISOS. 
Interoisciplinary activity included consulting in design of the case investigation questionnaire with assistance from Dr. Brian Parker, Forensic Srientist; Mr. Steven Oüra, Research Sociologist; SRI legal council; and Dr. Peter Neumann and Mr. Carrol Kerns, Information Sciences.

This report includes a description and brief analygis of a case file of 129 cases of unauthorlzed acts involving computers, a sumnary of 19 cases involving multiaccess systems, a description of an empirical approach to threat analysis, and a detailed discussion of the nature of threats to computer systems. The report concludes wi th a summary report of the reaction and position of the computer manufacturing industry toward threats to computer systems.

The following conclusions were reached as a result of the research:

- Computer manufacturers claim incongruity between the federa1 and stote governments on one hand, which demand security in standard computer products, and most commercial customers on the other hand who are unw1ling to pay for such security.

- Demand for secure computer systems among conmercial users will ultimately come about from leglslation forcing securlty precautions and awareness of publicized, major computer-related crimes and the growing vulnerability of their organizations as they rely more heavily on electronic data processing (EDP). This demand is just starting to be noticeable.

- Security problems in multiaccess computers are rapldly approaching solution. ${ }^{4}, 4$ The remalning problems include positive personal Identification from terminals, auditability and certiflcation of computer security, metrics for the degree of computer security, cost-effective application of security features, and development of a body of knowledge of real breaches of computer security as an aid in optimally distributing security resources.

- Empirical threat models dertved from actual experience are equal In importance to theoretically derived threat models in design and testing of secure computer systems.

- It appears feasible and practical to formalize the investigation methodology and analysis of unauthorized acts involving computers that result in damages, losses, and injuries. This formalization 
will allow aggregation of data to validate threat models for use In developing and certifying the security of computer systems.

- The recording of 129 computer-related incidents, Investigating many of them in varying degrees, and comparing the incidence and losses to the growth of computer usage indicate a significant new sociai problem.

- Conclusions from the case studies are applicable to computer security research and development:

- Computer security should be developed on the basis that a penetrator of a computer system knows as much about the security features as the designers and implementors.

- Security measures within a computer system at the present stage of development can be only as effective as the physical and personnel security surrounding the system.

- Detection and effective reporting of anomalous activity within a computer system and its environment is equally as important as prevention of unauthorized acts.

- All persons having access to a computer system should be aware of bounds within which they may operate and should be warned of possible sanctions for overstepping those bounds. The equivalent of NO TRESPASSING and DO NOT... signs should be visible to any user who exceeds or attempts to exceed security bounds in a system.

- Unpredictable reasoning of unauthorized system penetrators precludes the effectiveness of assuming that a penetration work factor or bribe level of privilegen system personnel greater than the worth of the assets protected is a measure of adequate security.

- Monjtoring the use of computers could be important for detecting the possible planning or practicing for attacks on computers.

- A controlled access feature is of little value unless all attempted violations of it can be reported to the appropriate authorities in a timely manner for effective action. 
- A significant increase in multiaccess system cases can be predicted on the basis of the proliferation of multiaccess systems containing, controlling, and processing valuable assets. The historic laissez-faire philasophy of computer users toward proprietariness of data, programs, and computer services and the user's image of the computer as an attractive subject of attack but not possessing personal attributes are factors that support this increase. 


\section{EMPIRICAL APPROACH TO THREAT ALALYSIS}

As with any area of research, a problem or chnllenge must cxiat to prompt such research. Research in security for computer systens used to be similar to nuclear reactor safety where few, if any, real disasters occurred, yet safety precautions had to be developed and made effective. Now, however, a small body of knowledge of reported cases of intentional acts against computer systens exists. The approach to computer security research need not be limited to theoretical considerations, ponetration exercises, and well-circulated myths of computer crimes. There are enough real cases of unauthorized activities to support clatms of increasing seriousness of the problem to justify accelerated security development efforts and enough real cases for analysis and conclusions about the threat. Real cases are superior to theoretical penetration. exercises in some ways because they are occurring mere frectuently, they embody rational as well as unpredictable human behavior under natura? stress, and they occur in real, undisturbed environments. Theoretical exerctses are superior to real cases by being able to test spectfic security features under rigorous conditions in experimental systems, Thercfore, botis theoretical and empirlcal threat analysis is needed. Figure 1 illustrates how this process can be carried out in the overall research context.

Before proceeding to the next step of analyzing the nature of thrents to computer systems and model development in Section $v$, the data base of case histories on which the analysis is based is described. 


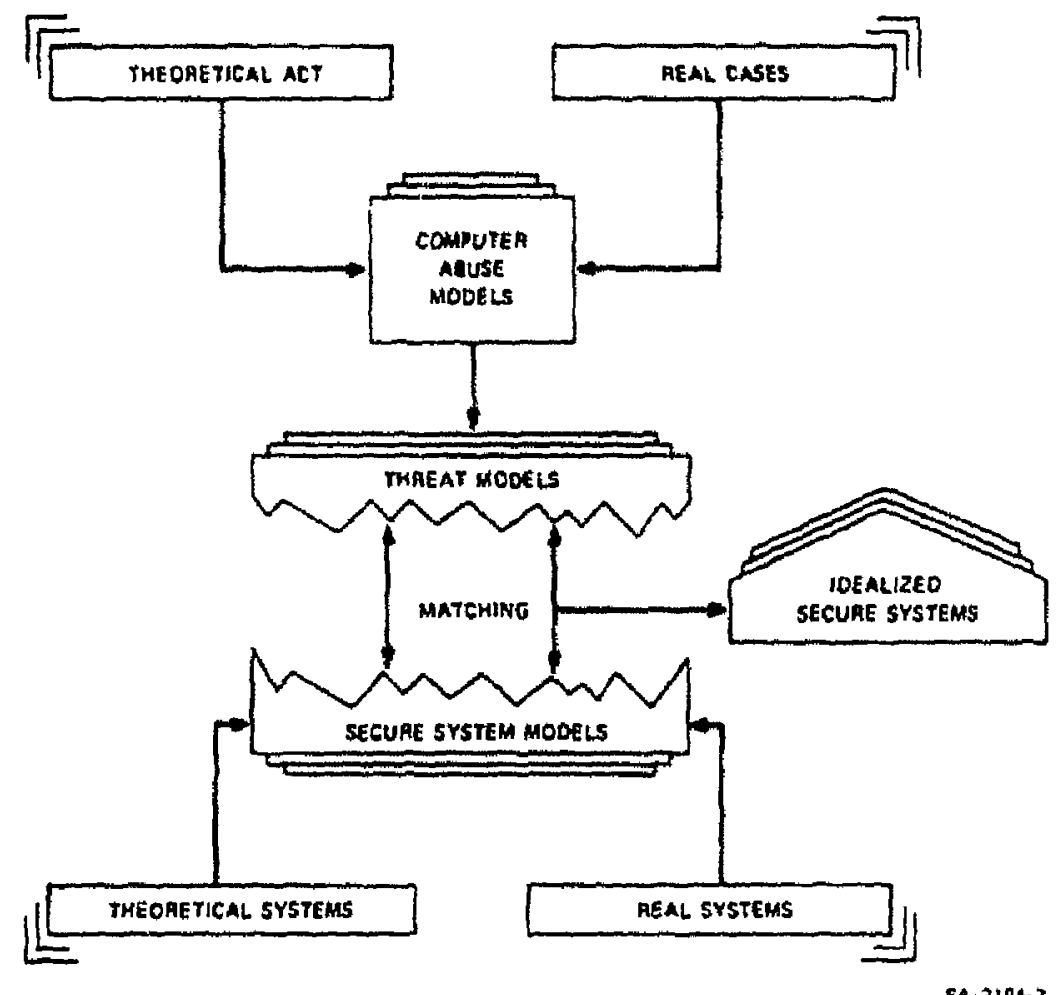

FIGUAE I THREAT ANALYSIS METHODOLOGY 


\section{UNAUTHORIZED ACT CASE HISTORY DATA BASE}

The case flle of unauthorized acts has increased to 129 reported incidents, with the addition of 38 since september 1972 when the project Ior MISOS started. (Sec Appendix F for summartes of new cases.) A total of 46 eases has been veriffed on the basis of direct contact, with one or more people involved or associated with each case. Severral cases have been investigated in detail and documented in the appendix of the investigation Manual.

Statistics dratn from the case file must be carefully qualified in renching conclustons. Only 21 cases were privately reported; the remainder were discovered througl news media stortes, trade journal articles, talks, tecinical papers, and legal documents. Studies in criminology generally agree that about 15 percent of known cases of all types of cilite are reported to law enforcement agencies. Applied to computerrelated crimes, a rile of 100 cases known and reported to police would tmply that over 660 known cases are not reported to the police. Knowledgeable persons working in CPA firms indicate that a file of 129 cases covering a span of nine $y$ cars represents on $2 y$ "a piece of the top of the lceberg of kinat's really going on." The assistant district attorney who prosecuted a recent case of program theft indicated that he has never cneountered another professton in which so many unethical and potentially 11leg: practices abound.

i time-lag phenomenon accurs in reporting cases. This is evident in figure 2 which shous a frequency distribution of incidents recorded when onty 82 cases were known in April 1972 and now in March 1973 when 


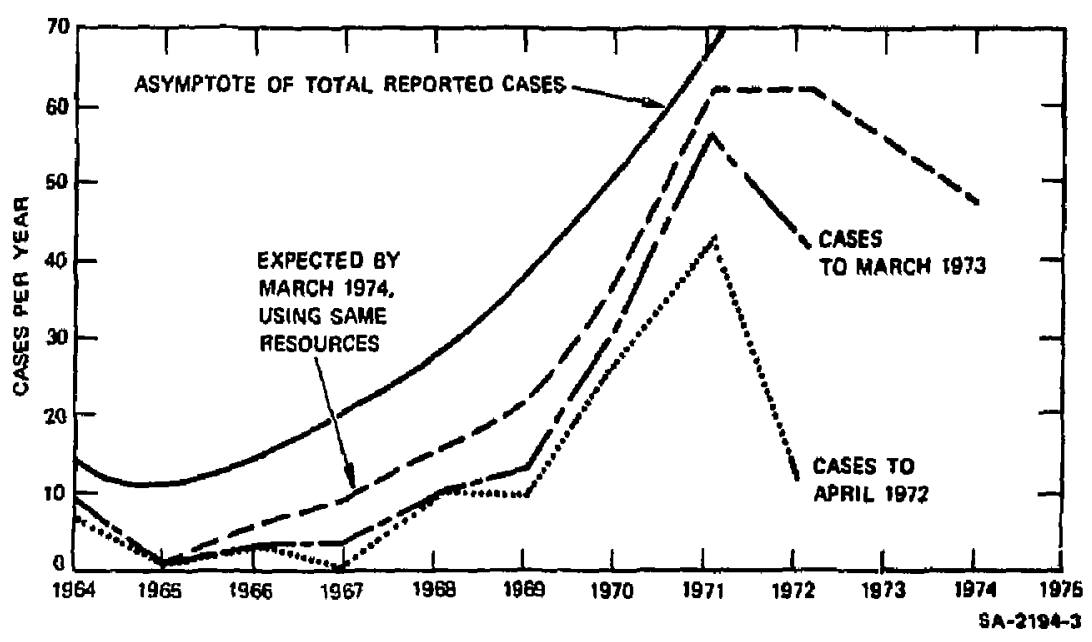

FIGURE 2 FREQUENCY DISTRIBUTION OF INCIDENTS

129 cases are recorded. It may be several years before a case is found or people are willing to reveal it.

Table 1 is a summary breakdown by year and by type of incident. Also shown are the number of verified cases. It is expected that counts for 1972 will soon exceed those of 1971 and, similarly, those of 1973 . It must be realized that these numbers are also influenced by changing social conditions and attitudes that affect the willingness of victims to reveal the1r misfortune and of the public media to report them.

Computemworld weekly newspaper was the source of 48 of the 128 cases. The newspaper subscribes to several clipping services covering most newspapers for computer-related incidents and makes a practice of reporting most of them. An increasing number are being reported privately and directly to SRI as it becomes more widely known that the research project is collecting such information. 
Table 1

CASES BY YEAR AND TYPE

(To Case 6924, 3/5/73)

\begin{tabular}{|c|c|c|c|c|c|c|}
\hline & Vandalism & $\begin{array}{l}\text { Information or } \\
\text { Property Theft }\end{array}$ & $\begin{array}{l}\text { Finnincial } \\
\text { Eraud or Theft }\end{array}$ & $\begin{array}{l}\text { Unauthorized Use } \\
\text { or Sales of Services }\end{array}$ & $\begin{array}{c}\text { Verifiod } \\
\text { Cages }\end{array}$ & Total \\
\hline 1964 & & 1 & 3 & & 2 & $A$ \\
\hline 1965 & & & & & & \\
\hline 1966 & & & 1 & & 1 & 1 \\
\hline 1967 & & & & 1 & & 1 \\
\hline 1968 & 1 & 1 & 4 & & 1 & 6 \\
\hline 1969 & 3 & 4 & 1 & & 4 & 8 \\
\hline 1970 & 7 & 5 & 6 & 5 & 11 & 23 \\
\hline 1971 & 6 & 15 & 19 & 6 & 12 & .16 \\
\hline 1972 & 5 & 34 & 9 & 8 & 13 & 36 \\
\hline 1973 & 2 & 1 & - & 1 & $\underline{2}$ & 4 \\
\hline Total & 24 & 41 & 43 & 21 & 16 & 129 \\
\hline
\end{tabular}


It was assumed until recently that the United States is unique in proliferation of computer-related crime. However, al of the cases ocm curred in other countries, mostly in Hestem Europe. Unauthorized acts occur wherever computers are located.

It appears that no other organization is making an exhaustive attempt to collect, analyze, and report on computer-related crime data. The Internal Revenue Service has investigated a fer' of the more highy publicized cases. Dennie Van Tasse at the University of California, Santa Cruz; Jerome Lobel, ${ }^{6}$ a computer security consultant in Phoenix, Arlzona; Brandt Allen, University of Virginin; and Reiner von sur Muhlen, ${ }^{7}$ a consultant in Bonn, West Germany, collest cases from newspaper stories and through personal experience with clients. Gerald Mckinght, a professional author of Surrey, England, is writing a popular, nonfiction book on the subject.

Some valuable conclusions have already been reached in study of this limited data base, although they may change over the long term as it result of such factors as shifting social values, advancing computer technology and security methods, and proliferation of computers in bringing about the paperless society. The und versal use of the questlannaire developed as part of this research (see appendix D) to document and model each incident in the file will ald greatly in renching additional conclusions and supporting findings from other sources. Data from the completed questionnaires can be used to provide frequency of occurrence of common factors and circumstances. Cross tabulation, multivariate and causal path analyses, and correlation of the data should reveal useful information. Some of the dimensions of statistical studies can include:

- Types of assets affected or threatened

- Location of such assets

- Purposes of the acts 
- Positions of perpetrators af acts

- Bnckground of perpetrators of nets

- Knorledge, skijls, and access of perpetrators

- Types of accoss and entry to the computer

- Roles played by the computer and comminicntjons

- Types of computer systens and peripherals involved

- Types of software

- Types and extent of security subverted

- Methods of detection

- Methods of detection avoidance. 


\section{SULMARY OF MULTIACCESS SYSTE!I CASES}

Reports of 19 cases of a total of 129 cases on f1le involved multiaccess computer systems, Two of the cases are thefts of entire operating systems and occurred in 1971. The remaining 17 occurred since 1969 and concerned terminal access using system commands. Five of these cases were imited to input/output manipulation of applications. Seven cases Involved penetration of the operating systems. Four of the seven were to obtain unauthorized use of services; one was industrial espionage; another was vandalism; and the purpose of the last is undetermined. Five of the 19 cases occurred in university envi ronments, the rest in businesses.

These 19 cases represent only 15 percent of the recorded cases. This is probably because of the small number of multiaccess systems compared with on-site batch systems in operation in the 1969-72 period. It is also caused by a time lag in discovering known incidents and a suspicion that more multiaccess system penetrations are not detected compared with the more obvious physical access usually associated with other types of systems,

The total number of cases and the number of multiaccess cases rould be far higher if a methodical search were conducted among academic institutions. Although more unique and sophisticated methods would probably be discovered, less serious damage, loss, or injuries would be encountered than in business and government environments. However, there is a sinister potential to probable proliferation of the incidence of acts in an academic environment. Students rationalizing these acts as games and iegitimate challenges with relatively benign results could produce a generation 
of computer users in business and government with different ethical standards and great expertise in subverting computer systems. A study of cases in academic environments and a study of the attitudes and social values of students gaining such expertise is suggested and would be valuable in predicting the trends and nature of computer-related crime.

A significant increase in multiaccess system cases can be predicted on the basis of the proliferation of multiaccess systems containing, controlling, and processing valuable assets. The historic laissez-faire philosophy of computer users toward proprietariness of data, programs, and computer services and possibly the user's image of the computer as an attractive subject of attack but not possessing personal attributes are factors that suppodt this increase.

Discussions with managers and systems programiners from computer time-sharing service companies, including four perpetrators of unauthorized acts, indicate that it is common practice to gain legitimate or unauthorized access to competitors' systems. Once gaining access, the perpetrators test the system's performance and features, take copies of programs and data files, test the security access control, and on penetration into privileged mode take private information and subvert the operating systc: making subsequent attacks simple. As a final act, they usually crash the system. In one example, the perpetrator was discovered by the victimized company and hired by the company to plug the holes he had found and made in the system. This young, bright systems programmer performed the penetration by adapting his knowledge and skill of his own company's system to the subject system. He rationalizes that this type of activity is not unethical or illegal and challenges anybody to prove that it is in the absence of legal precedence, contractual agreements limiting activity, or visible protective signs or warnings. 
A trend of increasing incidence could be reversed by increasing the security of systems to a degree that only the most knowledgeable systems programmers associated with a system could penetrate it by establishing norms of professional conduct inhibiting such activities and by providing detection and warning features to confront an individual with the nature of his act and as a basis for legal action,

These data and conclusions are put into the context of the nature of threats to computer systems in the next section. 
$\checkmark$ MODELS OF THREATS TO COMPUTER SYSTEMS

Models are most effective in understanding the nature of threats to computer systems. These models can be used in the design and development of technological and social means to reduce the incidence and serfousness of the misuse of computers. Models of secure computer systems have become quite common.

Several threat models in varying degrees of detail and validation have been constructed. First, a parameterized model in the form of a questionnaire and checklist was constructed (see Appendix D) for use in the investigation of cases. An investigation methodology was developed and presented in a Manual for Investigation of Computer-Related Incidents of Intentionally Caused Losses, Injuries, and Damage. The appendix of the manual contains two completed questionnaires that represent paramen terized models of two cases investigated in detail.

A conceptual model of the roles that computers play in incidents is described in Figure 3. A computer can be the subject of an incident. For example, several computer centers have been destroyed. Two thefts of small computers are known. In two cases, computers were shot with pistols by angry persons involuntarily and incorrectly served by computer applications.

Computers provide a unique environment in which acts occur. The uniqueness comes about in the new ways assets may be stored, processed, and transmitted. Computer programs represent entirely new types of assets created in this unique environment and subject to criminal and injurious acts. The largest number of 129 recorded cases fits into this category. 

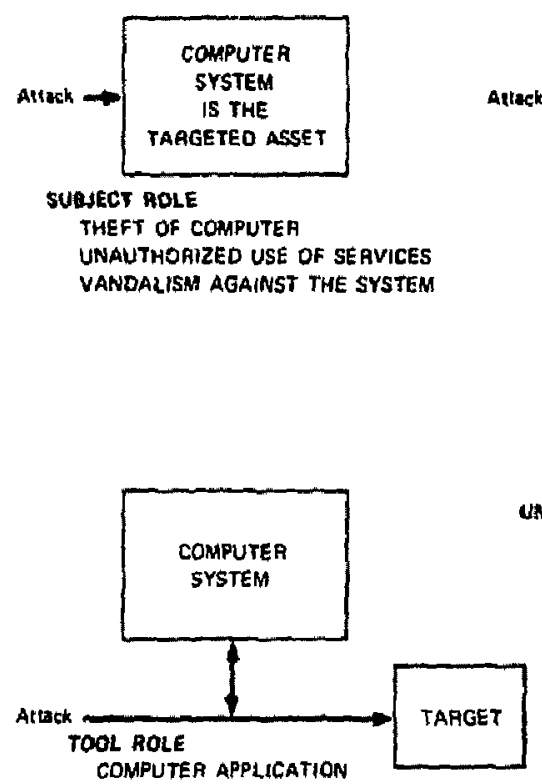

USED IN PERPETRATING AN ACT

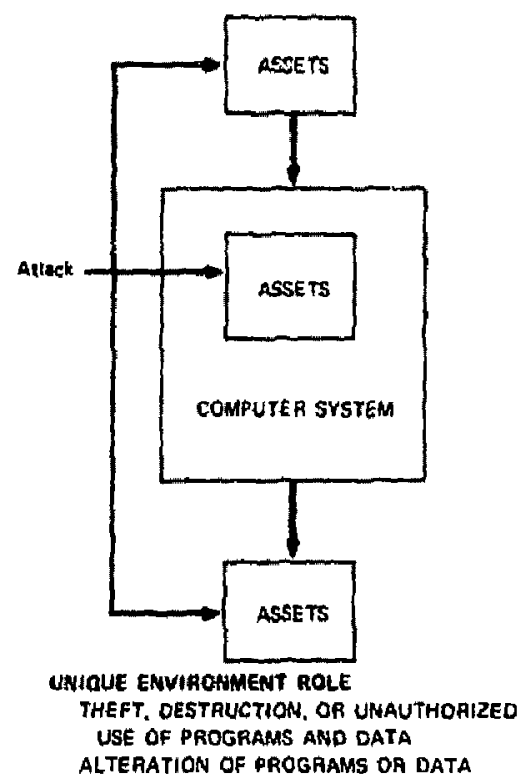

ALTEAATION OF PROGRAMS OR DATA

$5 A-2194-4$

FIGURE 3 ROLES PLAYED BY COMPUTERS

Finally, computers can play the role of tools used to perpetrate acts. The acts need n.t be uniquely assoclated with computer technology, but the tool and often the methods are. In one case, a computer was used to regulate the rate and distribute among accounts the embezzlement of $\$ 1$ million over six years. Computers can also be used to decipher password systems or encrypted information to penetrate other computers. Among the three roles played, it is likely that a breakdown of the unique environment role into subroles appears most fruitful in further 
understanding this subject. A study of the role of computers as tools in these acts andidates how Important it is to a perpetrator to have access to a computer to develop the method of attack and to practice the attuck to be mide on a similar computer. This leads to the conclusion tliat monitoring the use of computers could be an important part of computer security in detecting possible planning or practicing of acts.

A sequential flow chart model as presented in Figure a can be a helprul device for understanding these acts. This model sugrests that the attack (in box 6) may represent only a small part of an incident. Current computer security concentrates on this one pspect, probably because it is most amenable to teclinological solution. This model could be concelved as a threat model, and a comprehensive development of computer security should address each box in the diagram. For example, controlled access features in a computer system should be designed so that che appropriate witnesses (box 7) can and will observe at tacks in a timely manner.

Box 9 ending without detection could mean less than successful results for some perpetrators. Several cases indicate the importance to some perpetrators of having the success of their efforts known, for some people, it would be frustrating to not be able to boast of a successful act. This is a significant aspect of the Jerry Schneider/PT\&T case (see Appendix $c$ ). In a recent delayed-action computer penetiation at Dartmouth University, the perpetrator had a complete confession stored as a file in the system he successfully attacked.

Another way to depict an incident is by a conceptual outline model, Table 2. It is divided into parts conceming perpetrators, subjects, and objects of the attack; planning; execution of the acts; detection; apprehension; sanctions; and recovery. This model provides a checklist for considering all aspects of an incident and is useful for devising 


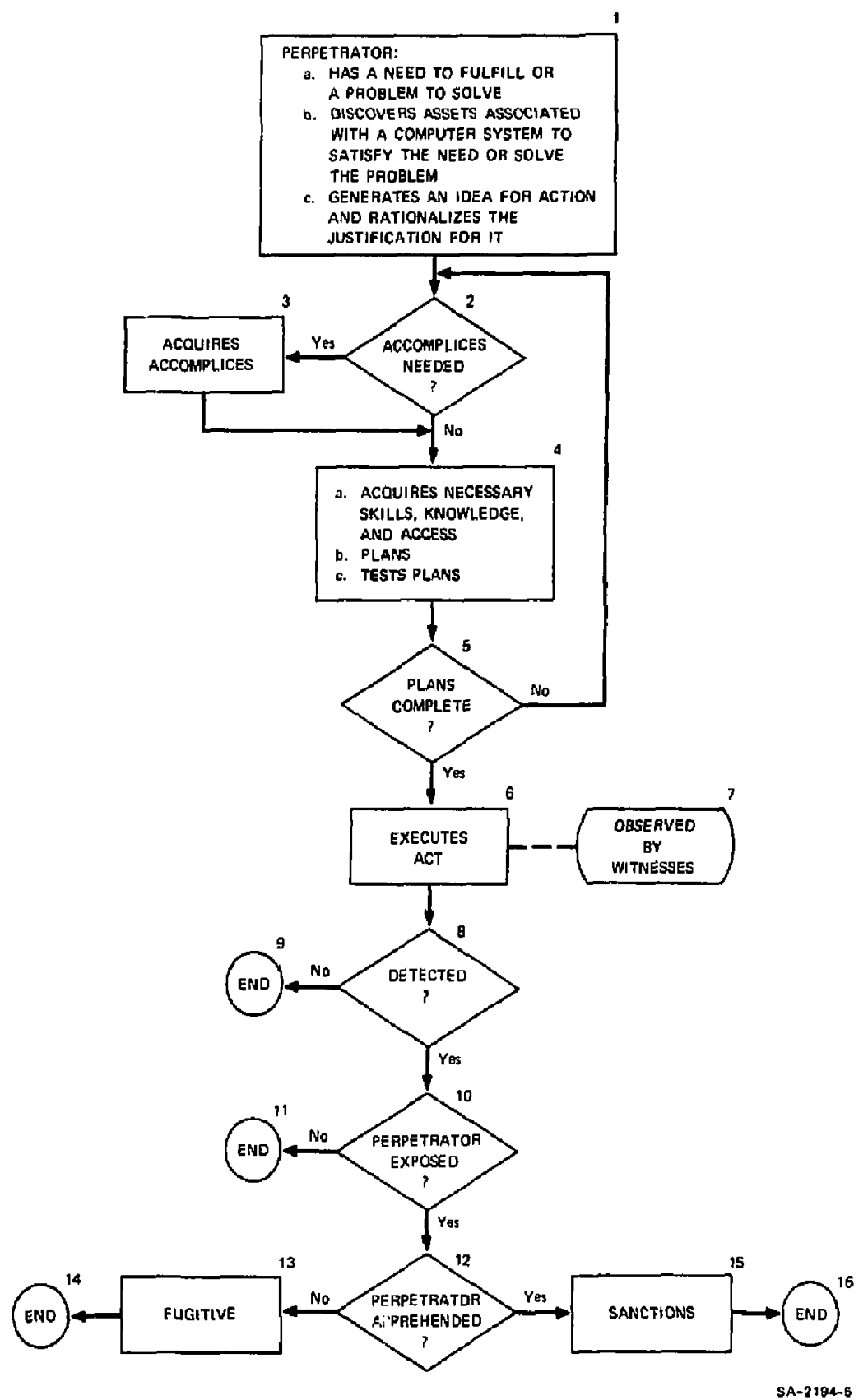

FIGURE 4 SEQUENTIAL FLOW DIAGRAM MODEL OF AN INCIDENT 
Lant: +

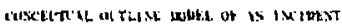

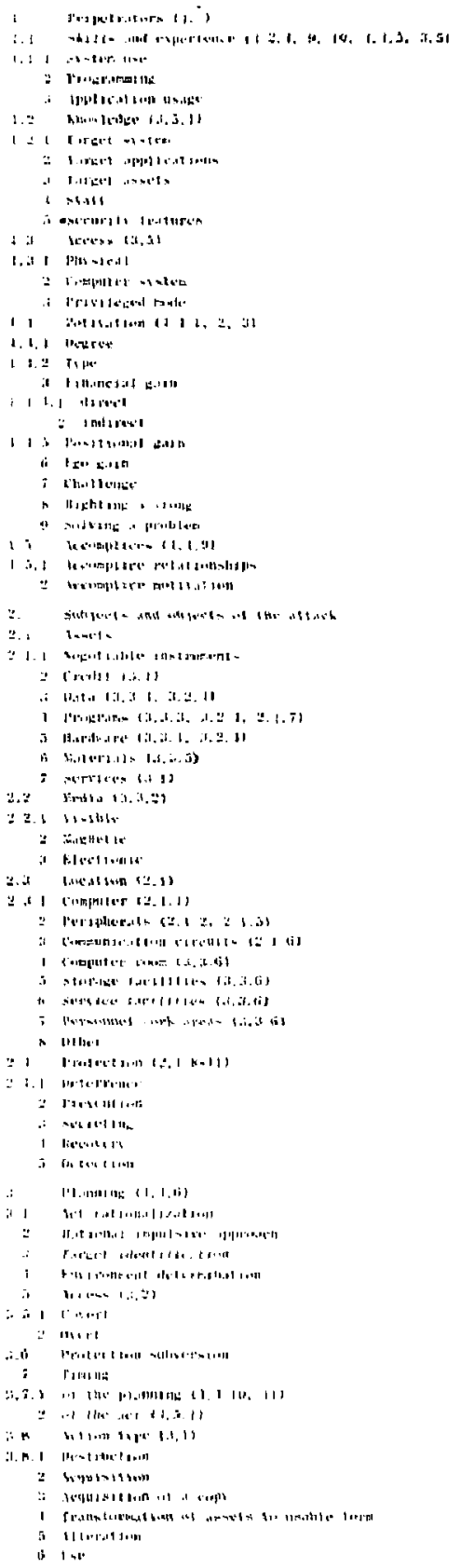

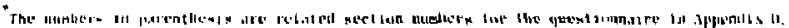

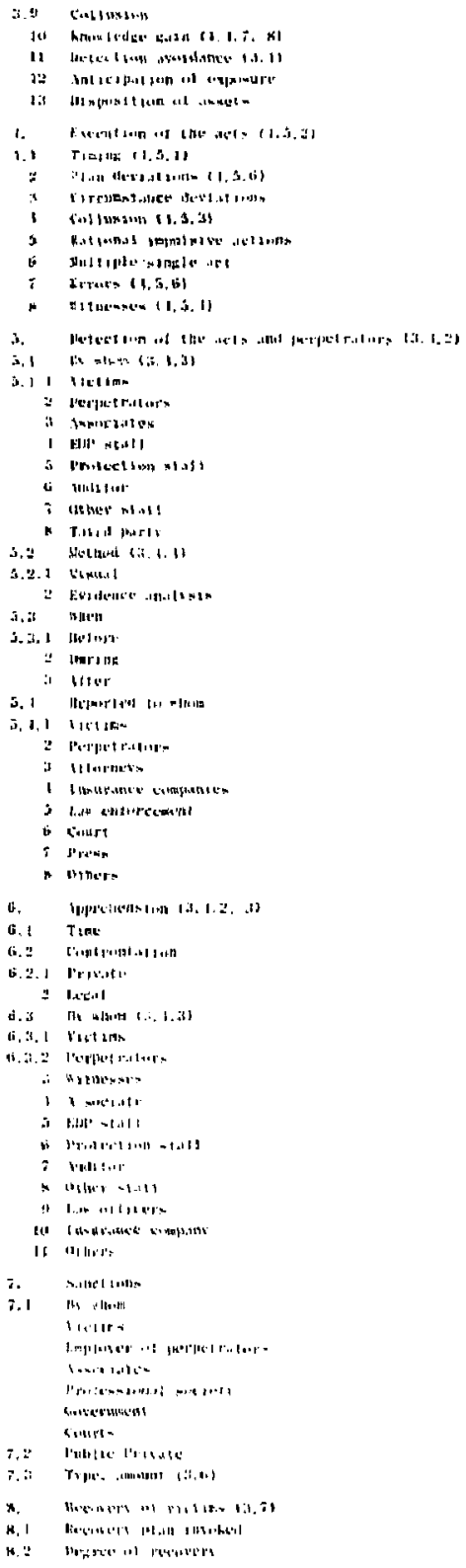


Investigative approaches. For example, the questionnalre in Appendix $D$ is related to this model by noting questionnatre section numbers following items in the outline model. Each major gubject in the outline is discussed below.

Perpetrators--A profile of perpetrators is based on acquaintance with six known perpetrators and on technical writing in criminology by Cressey and others.

Perpetrators are white-collar amateurs rather than emotional or professional criminals. Few women have been encountered, and when involved they tend to be accomplices employed as keypunch operators or clerks. Most perpetrators are 18 to 30 years old. A few of the embezzlers are older.

The best way to identify a potential population of perpetrators is on the basis of the unique skills, knowledge, and access associated with computer systems. These are the most important factors to consider in threats to computer systems. Professional criminals do not appear to have acquired the knowledge and skills yet (see the report on prison EDP training in Appendix 8 ), and the effort requiled will limit the number of them relative to the probable number of skilled, manual criminals.

Designing security into computer systems assuming that perpetrators will not be aware of all the algorithms used is an exercise in futility. The principal threat against whom protection is required must be the penetrator who knows as much about the system as the designers do.

Motive is a less helpful means of ldentifying potential perpetrators. The challenge of penetrating systems is attractive to many programers and has produced a small population of so called "system hackers" mostly in university environments. Most perpetrators have rationalized part or all of thelr acts. In fact, they often put more effort into rationalizing 
thei $r$ acts than in planning them (see the report on Jerry Schneider in Appendix C).

Perpetrators' acts often tend to deviate in only small ways from the accepted and common practices of their associates. In one case of program theft through a terminal, it was revealed in the trial that programners in both the victim firm and perpetrator's firm were gaining access to each others' computers frequently. This is called the differential association theory by Sutherland, ${ }^{9}$ the criminal psychologist who established the term, "white collar crime."

Another commonly found rationalization is the Robin Hood argument. Porpetrators tend to differentiate between doing harm to individual people, which is immoral, and dotng harm to organizations, which they belleve is not irmoral. In fact, they often claim they are just getting even for the great harm organizations do to society. Jerry Schneider, one of the known perpetrators, said that he was motivated to perform his acts to make money, for the challenge of seeing how far he could go, and to get even with the telephone company which he believes does great harm to society.

It is concluded and strongly supported that perpetrators fear unanticIpated detection and exposure. They tend to be highly motivated and amenable to meeting challenges. This makes detection as a means of protection at least as important as deterrence and prevention. Perpetrators tend to be amateur, white-collar criminal types for whom exposure of activities would cause great embarrasment and loss of prestige among the1r peers compared with professional crimtnals who are in a culture in which reactions are just the opposite,

Collusion is an important aspect of reported cases, occurring in at least 57 of 129 cases and seven of the 19 multiaccess system cases. Collusion is probably motivated by the differential association theory and 
the need for different skills, knowledge, and access as a result of the complexities of computer technology.

Subjects and Objects of the Attack--ihe subjects and objects of attacks contribute to the uniquenoss of computer-related crime. For example, as the cashless, checkless society approaches, financlal crimes will entail transfers of credit rather than dealing with negotlable instruments. Magnetic and electronic media make assets more compact, easily and speedily transmittable, and potentially easler to protect and hide. Data and programs are mare subject to theft by copying where the victim may not be denied continued use.

Computer programs represent a new asset subject to theft and theft by copying. The law frequently does not cover computer programs as subjects of theft. Theft law covers programs in Texas (Texas vel dus Hancock, 1968), but not necessarily in California (California versus Ward, 1972). The treatment of prograns as properties is in transition relative to taxes, patents, and declaration of ownership. The ethics of using modifying, and taking others' programs is not clearly defined. Programs as property subject to theft will require further economic, political, and jurisprudential attention.

Time is an important aspect of assets. Computer time (usage) and its availability when needed constitute an important asset. The value of computer-related assets changes more rapidly than equivalent assets is manual systems.

New assets, theif increased sensitivity to time, and new forms of assets in the new enrivonments of computer and commnication systems clearly require new approaches in protecting them from new types of threats. 
Planning--Planning an act can take great care and resources to be successful. Planning the peretration of a computer system is susceptible to failure because small changes in the software can ceuse large changes in penetration wethods. A bug in a program to be used for attack can easily be fatal to a sophisticated act. P: rposeful, minor changes in operating systems could be a useful security practice, although none of the reported cases indicate this yet.

The cases studied Indicate that planning tends to be highly rational, not impulsive, and often requires expenditure of great time and resources. Jerry Schneider (see Appendix C) posed as a magazine writer, an employee, and a customer over a six-iveek period to become an expert on operating his victin's computer system.

Execution of Acts-There may be important legal questions as to what constitutes an act associated with computers. For example, does an act occur with the unauthorized changing of a program or each time the altered program is executed?

Delayed action methods can be complex. In ox. case, a Trojan Horse technique was used by imoedding instructions in an ordinary file maintenance utility program. These instructions performed a check of privilege level each time the program was used. Six months after the program was put into general use a computer operator ran the program at a sufficiently high privilege level to trigger the program to take over the operiting system and establish a new resident, privileged program within the operating system that proceeded in tum to eliminate all the unauthorized instructions that produced it. Other cases have occurred where the acts are triggered by putting in dates and certain combinations of date or by occurrence of other events. These triggered actions occur when the perpetrator is in gi me relatively safe position to gain from the act and not be caught. 
Detection of Acts and Perpetrators--Detection is an important aspect of protection of computer systems. As indicated earlier, perpetrators tend to greatly fear detection. Detection features within a computer system can be made difficult to subvert compared with prevention features that must be fixed in action and in fixed locations within the system to protect similarly located assets. Detection techniques, on the contrary, may be placed anywhere, can be easily moved, and parameters describing detection patterns and tolerances can be frequently changed to values unknown to potential perpetrators even though they may know the detection methods used. For example, three unauthorized at tempts to use privileged system commands by a user within a specified time period may require more detalled monitoring of that user's activities and trigger an alarm at the operator's console to take precautionary actions. This level of monitoring may be too costly on a continuous basis. Therefore, it could be varied in frequency of application, number-of-attempt limlts and time limits, thus keeping a potential penetrator off-balance unless he can subvert the detection feature or the person changing the parameter values.

Few among the reported and discovered cases were detected by those directly responsible for detection such as security officers or auditors. Discovery was usually accidental and resulted from the curiosity of programming, marketing, or operations staff about unusual activities. Below is a summary of detection that occurred in several cases.

\begin{tabular}{lll}
\multicolumn{1}{c}{ Case } & Detector & Detection Method or Reason \\
$\begin{array}{l}\text { Unauthorized snooping } \\
\text { in a time-shared system }\end{array}$ & Operator & $\begin{array}{l}\text { Detected scratch tapes being } \\
\text { read before written, }\end{array}$ \\
$\begin{array}{l}\text { Time-delayed, Trojan } \\
\text { Horse penetration of } \\
\text { a time-shared system }\end{array}$ & Programmer & $\begin{array}{l}\text { Noticed a foreign program in a } \\
\text { dump of the operating system } \\
\text { resident. }\end{array}$ \\
$\begin{array}{l}\text { Theft of a program from } \\
\text { a remote job entry sys- } \\
\text { tem }\end{array}$ & $\begin{array}{l}\text { Noticed a proprietary program } \\
\text { deck that had inadvertently been } \\
\text { delivered by hand to a customer } \\
\text { who had not requested it. }\end{array}$
\end{tabular}




\begin{tabular}{|c|c|c|}
\hline Case & Detector & Detection Method or Reason \\
\hline $\begin{array}{l}\text { Bank application } \\
\text { program patched to } \\
\text { avoid overdraft reports }\end{array}$ & Accountant & $\begin{array}{l}\text { Noticed overdraft condition } \\
\text { when manual process } \perp \text { g replaced } \\
\text { a computer that had failed. }\end{array}$ \\
\hline $\begin{array}{l}\text { Pension payment check } \\
\text { fraud }\end{array}$ & Accountant & $\begin{array}{l}\text { Noticed an unusual number of } \\
\text { death notices of pensioners } \\
\text { following the existence notice } \\
\text { deadline. }\end{array}$ \\
\hline $\begin{array}{l}\text { Unauthorized sale of } \\
\text { dossiers stored in a } \\
\text { police system }\end{array}$ & Programiner & $\begin{array}{l}\text { Placed a patch in the system to } \\
\text { notify operator of a retrieval } \\
\text { request for a specified name to } \\
\text { trap the terminal user requesting } \\
\text { it. }\end{array}$ \\
\hline $\begin{array}{l}\text { Unauthorized penetra- } \\
\text { tion of a time-sharing } \\
\text { system }\end{array}$ & $\begin{array}{l}\text { Operator, } \\
\text { telephone } \\
\text { company }\end{array}$ & $\begin{array}{l}\text { Noticed an unusual number of } \\
\text { crashes. Terminal used was } \\
\text { traced by the telephone company. }\end{array}$ \\
\hline $\begin{array}{l}\text { Unauthorized use of } \\
\text { time-sharing services }\end{array}$ & Operator & $\begin{array}{l}\text { Noticed an unusual frequency of } \\
\text { requests for game-playing } \\
\text { programs. }\end{array}$ \\
\hline
\end{tabular}

Apprehension, Sanctions, and Recovery--These three sections of the model deal with subjects not of direct interest to RISOS and are included for completeness purposes only.

The reactions of potential victims of the threats described in this section are evaluated in the next section indirectly by considering the problems that computer manufacturers face in marketing security-oriented computer products. 


\section{REACTION AND CURRENT POSITION OF COMPUTER MANUFACTURERS TOWARD THREATS TO COMPUTER SECURTT}

Computer manufacturers are gaining experlence in developing new systems and modifying existing ones to incorporate security features; however, this is being done only for isolated, individual custoners-mostly federal and state government agencies and several large banks and time-sharing firms. Otherwise, the manufacturers are caught between the demands of federal and state governments for security built into standard products and commercial customers' unwillingness to pay isr security features.

Each computer manufacturer has one division or more with experience in developing secure features in computer systems; but in most companies the concern and experience do not pervade the commercial products divisions to any extent. Burroughs has a corporate staff man with part-time responsibility for security in products. Honeywell has a newly appointed staff headed by Jack Bremer in Phoenix concerned with standard product security; Control Data and Singer have no central responsibility; Univac has a committee as a focal point; and IBM has a full-time staff, headed by Robert Courtney in the Systens Development Dirtsion and Larry Foster leadıng a staff in the Federal systems Division dolng research, with the Resource Security system as a test vehicle.

The primary inhibiting factor is the lack of willingness of most customers to pay for security in the computer products they buy. Small segments of interested computer users have developed among bank credit reporting services and time-sharing services. Manufacturers also do not 
see their customers ereating secure physical faciltties for their computers to match the degree of security posstble in computers at even mociest cost.

Another problem concerns the sensitivity of the secure state of an operating system to software changes. A manufacturer could produce an effective, controlled access system only to have the customers, continuing their common practice, modify the software and add other manufacturers' hardware, thus violating the integrity of the system. The Inhibiting constraints and extra care required in updating a secure operating system precludes maintaining security in a computer system in today's typical computer facility environment. Several large time-sharing services are Iearning to maintain secure operating systems Independent of the manufacturer, but it requires resources and a disclpline beyond the means and motivation level in private, in-house computer facilities.

Secure features are gradually being incorporated into standard products at the level of preventing accidental or intentional incidents that result in losses, injuries, or damage. However, serious penetration attexpts cannot be thwarted. Burroughs appears to be advanced at file access and sharing control at subfile (record or item) levels. Security is vested in the computer operator, and an extensive security monitor $\log$ is produced in the 6700 system. Honeywell's new 6180 Central Processor is advanced in integrated hardware and software security. Distributed authorization at the Iowest user level is provided. IBM's newest os releases are greatly 1mproved in controlled access aspects. IBM provides extensive assistance to customers in the overall security of their facilities. Honeywell, Burroughs, and IBM have cryptographic hardware products in limited use and ready for general marketing when the demand arises. They also have made advances in methods of automatic identification at terminals that may result in products being available in 1973 for use in specialized applications such as point-of-sale transaction systems. A11 
manufacturers expect legislative actions over the next several years that will affect the secure computer system market.

Individual reports on visits with computer manufacturers are in Appendix A. Reports on visits to MIT, Tymshare Corporation, TRW Systems, TRW Credit Data, and Rohr Industries are In Appendix B. 


\section{REFERENCES}

1. D. B. Parker, The Nature of Computer-Related Crime, Proc. International Conference on Computer Communications, ACN/IEEE (October 1972).

2. J. P. Anderson, Information Security in a Multiuser Computer Environment, Advances in Computers, Vol 12 (1972).

3. A. M. Noll, The Interaction of Computers and Privacy, Executive Office of the President. (Unpublished) February 12, 1973.

4. Dennie Van Tassel, Computer Crime, AFIPS Proc. Vol 37. FJCC, 1970,

5. Jerome Lobel, Privacy, Security, and the Data Bank, Government Data Systens (November 1970).

6. B. R. Allen, Computer Security, DPMA. Data Management (January 1972).

7. J. Turn and N. Shapiro, Privacy and Security in Databank Systems, AFIPS Proc. Vol 41. FJCC (1972).

B. D. R. Cressey, Other People's Money, a Study in the Social Psychology of Embezzlement, Wadsworth, Belmont, California (1971).

9. E. H. Sutherland, White Collar Crime, Dryden, New York, (1949). 
Appendix A

REPCRTS ON COMPUTER MANUFACTURERS VISITED 


\section{Appendix A}

\section{REPORTS ON COMPUTER MANUFACTURERS VISITED}

SRI visited a number of computer manufacturers as partial fulfullment of its contract with the RISOS Project at Lawrence Livermore Laboratory. Donn B. Parker, project leader, reports on these visits in the following pages. Computer manufacturers visited, the persons contacted, and dates of the interviews are listed below.

Burroughs Corporation, Large Systems Division, City of Industry, California--Mr. Don Lyle, Manager of Programming Activity (8 February 1973).

Control Data Corporation, Minneapolis, Minnesota--Mr. Robert Horris, Di rector of Advanced Strategy (15 December 1972).

Digital Equipment Corporation, Maynard, Massachusetts-Mr. Kenneth Olson, President (5 January 1973).

Honeywell Information Systems, Inc., Wellesley Hills and Wal tham, Massachusetts--Kurt Van VIandren, Public Relations, Nalcolm Smith, Education, Dr. John Weì1, Vice President (11 January 1973).

Singer Business Mlachines Systems, San Leandro, California--Dr, Clair Miller, Sof tware Development (19 Jamuary 1973).

UNIVAC Federal Systems Division, St. Paul, Minnesota--Frank Quirk (I5 December 1972). 
BURROUGHS CORPORATION, LARGE SYSTEMS DIVISION

This report concerns any interview wi th Don $M$, Lyle, Manager of Programming Activity in Burroughs Large Systems Diviston, who is responsible for all $B 6700$ Computer system software. Mr, Lyle indicated that Edward Lohse in Detroit is the corporate staff person rusponsible for computer security. He also suggested that Dean Earnest, Lyle's counterpart at Burroughs' small systems plant in Goleta, California, would be interesting to talk with especially since he has extensive experience in cryptology.

Burroughs is working on a personal identification product that is secret at present but may be announced this yoar in conjunction with the Burroughs cast-issuing, stand-alone teminals. Lyle knows Doug Hogan at NSA and indicated that NSA has done some security-oriented testing of the 86700 . Lyla noted the general reluctance of customers to pay for corputer security except for some goverment agencies, He pointed out inconsistencies in security comitment by the computing commuity by indicating that no ANSI standards take security into account-for example, tape file labeling.

86700 security features include memory proteation, probikiting users from using machine language, user identification and file access, anc sharing authorization by name and password. After initial computer assignment of a password, a user sircifies his own passwords. This has caused problems in reconstructing dis: packs of files when disk failures occur. There is no mechanism to identify user-generated file passwords. 
The 86700 has a whO I command to return the serial number identification of the computer, but this feature is used only to hide new software features until they are ready for release to customers. All software sold or licensed by Burroughs is copyrighted and carries a copyright label, but no secret marking to identify software is done. Complete annotated listings of the system software, about 50,000 Iines, are supplied to customers who frequently insert local changes and cause loss of any possible system security and integrity guarantees. system security is vested in the computer operator. Three monitoring logs of systern activity are generated: a job $\log$, hardware sailure maintenance log, and a security $\mathrm{log}$ to record all anomalous activity associated with security matters such as LOGUN failures. Only two attempts to LOGON are allowed before telephone disconnection is made. It is the customer's responsibility to do anything further with the logs.

A terminal-oriented file management and editing capability with extensive controlled access is provided. It allows sharing of files but only for reading or read/write. A new release will allow sharing and access control at the item level. The system maintains the creator of each file as the sole authorizing source. Lyle indicated it would take him about ten ninutes of desk and terminal work to make unautlorized penetration of the systom, but this capabilit, requires detailed system knowledge possessed by only a few peaple.

Mr. Lyle described a computer-related crime that occurred in London. Thts is documented separately from this report. 
COITHOL DATA CORPORATION

During my visit at Controi Data Corporation in Minneapolis on December 15, 1972, I talked with the following people on the corporate staff: Robert Morris, Director of Advanced Strategy, Howard Squires reporting to horris and responsible for computer security matters, David Jasper in Data Services under Robert Price and concerned with computer security, and a programmer responsible for 6000 Series file access methods.

Control Data is just starting to rear: to security needs. Those 1 talked with indicated no pattern of demands from customers for security in CDC products. They were unaware that the VIMI users group has a committee on security and privacy (Tom Elrod of CDC attended a meeting of the committee, but I didn't talk with him.) CDC has a contract to develop software for a Sulss bank which includes significant protection requirements (RISOS should investigate this further).

Data Services is concerned about security. Jasper indicated that he was dealing with George Goode, President of Datotek, about possible use of Datotek cryptographic devices for telephone circuits, Jasper thought this product was the best on the commercial market. He acknowledged that the product was applicable only to point-to-point transmission and not to a mulitiplexed configuration.

Cybernet has a serious accounting problem that may tie in with a problem reported by RISOS personnel, al though others di sagree with Jasper and think it is not such a serious problem. Data Services provides its analysts with a privileged account number with no individual accounting of its use, Misuse by analysts to help a customer beyond what 
company policy allows sometimes accurs. Large amounts of time are charged to this number occasionally (up to $\$ 10,000$ worth per month). Data Services has not yet decided what to do. Employee turnover and possible misuse of information by ex-employees is another significant problem.

Jasper indicated that in the CEIR segment of the CDC, valuable LP programs are kept on tapes in a form writable and readable only by special $1 / 0$ programs that put and contend with large numbers of parity and other errors, making them extremely difficult to read by standard I/o programs. Control Data disperses coded Identification data throughout its software packages offered for sale or lease.

It is Control Data policy that security is its customers' problem unless otherwise handled by special contract. Hooks are placed in standard product operating systems for customers who wish to add their own access control. Hardware features exclusively for security purposes are not made standard parts of products because not all customers are villing to pay for them.

Bob Morris is responsible for developing means of monitoring computer products delivered behind the Iron Curtain to assure intended types of usage only as stipulated in federally approved contracts. Larry Ingersman is developing the techniques under Bob. CDC is working jointly with IBM (Jack Bertram and Wal ter Lowd) on this effort. The approach is based on computation pattern analysts against normative profiles of approved application programs. The results of the analysis would be stored in fail-safe devices installed in the CPU from which recordings would be removed to diplomatic safes and couriers. Bob Morris wishes to be the COC contact for anybody interested in this activity.

I found CDC to be cooperative and willing to work with RISOS. 


\section{DIGITAL EQUIPMENT CORPORATION}

Ken Oison and Gordon Bell were visited at DEC on 5 January 1972. DEC does not usually get into applications of its computer products to avoid competition with its customers. Security features have not been seriously considered by DEC, since there is no significant customer Interest. Metal key locks on computer console panels are the only evidence of security awareness, Ken feels that to a great extent the computing community must rely on mutual trust and ethical practices.

DEC hardware products will become subjects of theft. A technician at DEC stole a FDP 8 a plece at a time and assembled it at home for his own use.

I nated a reasonable level of plant slecurity on my resit. However, the only restrooms for visitors in the main lobby are at the opposite end of what appeared to be the main computer room for software development. I was told to thread my way through a nearly complete set of DEC products in operational use to reach the men's room which 1 did without an identifying visitor's badge, 
HONEYWELL INFORMATION SYSTEMS, INC.

I visited Dr. John Weil at Honeywell Information Systems (HIS) on January 4, 1973; I also talked with HIS personnel engaged in operation of EDP training at Walpole Prison, but this is the subject of another report.

It is my impression that HIS has gone further than any other computer manufacturer in providing controlled access features in stanaard products with the planned announcenent on 17 January 1973 of the HIS $6180 \mathrm{CP}$. It will incorporate hardware features for access control as developed at MIT Project MAC in the MULTICS system. This is a relatively bold move, requiring all customers to pay for the additional security features whether they want them or not. The market is ambivalent, with the private sector generally uninterested in computer security and the federal sector pushing hard for $1 t$ in standard products. John thinks the other manufacturers are not taking sufficient responsibility and generally ignoring the need for secure systems or delaying action. He concluded this after attending the recent ONR conference.

John points out that, even if the manufacturer supplies the controlled access capability, it will be useless unless put into an already securityoriented customer enviroment. He is frustrated in pushing sophisticated security features when so many simpler measures could be taken but are not. He agreed that customers w1ll require secure systems only when they have been frightened into it by major catastrophes or axe forced into it through legislation and regulation. The computer industry should be acting as amicus curiae in the coming legislative restrictive actions and resistance of them by the computer users. He encouraged SRI's 
work in collecting and documenting factual information of actual computer-related incidents of unauthorized acts causing losses.

John agreed with my theories regarding increasing computer-related crime, decreasing general transactual crimes, and concepts of automation of security to reduce human involvement and the forcing of acts to require collusion. He felt that detection in contrast to prevention is difficult to consider because of the problem of defining the difference between the two. He said that MuLTICs has detection as backup to prevention, pointing out that prevention is meaningless unless 1 ts performance is detectable. He had not fully considered the concepts of dispersed versus centralized authorization control needs of different enviroments and referred me to the MIT people who have considered this. He agreed that the problem of proving and certifying the integrity of the hardware and software security features of a system is now the most difficult problen. He suggested the need for special specification and programming languages amenable to proof for socurity software. I suggested the possible need for a hardware feature for trace-backs of $\mathrm{CP}$ control transfers (possibly a register to hold the address of the last jump instruction ex scuted). The HIS MuLTICS system does not have the capability but it right prove useful.

UIS has designed a cryptographic product, but there is not sufficient d. ind for it yet. HIS also has designed a user identification device, bu the method uged is being kept secret. HIS has rejected voice recognition and hand measurement devices and feels 1 ts is superior to others developed so far.

John has formed a full-time computer security development staff in unix. Personnel Irom this group are planning to visit varlons Se irity-oriented project sites, including SRI and RISOS. 
SINGER BUSINESS MACHINES DIVISION

I visited Dr. Clair Miller, Director of Software for Singer Business Mlachines in San Ieandro, California, Singer has about 60 percent of the point of sale (POS) transaction terminal business. Its largest accounts are Kresge, Woolworth's and Sears. As a division it is now breaking even after several years of losses. Its main products include the System 10 computer system, peripherals, and POS terminals. These terminals are cash registers with special minicomputers with bardwired programs and outputting up to 60 registers of information over a twisted-pair wire at low speed ( $120 \mathrm{bps)}$ to a poling multiplexer into a computer, a System 10 , or IBM computer. One large output register at the terminal is used for computer to terminal messages currently limited to negative credit information to stop a transaction. The terminals can be poled for theoretical inventory status and cash on-hand. Clexk employee numbers and metal leys must be used to LOGON and activate a terminal.

Although it would be expected that security would be of vital importance in such POS procucts, there has been no customer demand for security features and Singer has 11ttle security-oriented product ReD ict. vity. Security research has a low priority, al though there is some work o srsonal identification. I suspect that customers are fitting terminals into cash register environments with little or no change from previous stand-alone facilitics. They probably have not yet experienced any different types of POS fraud than in the past and do not appreciate the potential of protection possible in an on-line environment.

John Hunt in San Leandro (357-6800, x2042) heads new product developtient and would be the approprdate person to contact for further information. 
UNIVAC, FEDERAL SYSTEMS DIVISION

I visited the Unt vac Federal Systems (Eagan) Plant in St. Paul, Minnesota, on December 15. A meeting with about ten people was arranged by Frank Quirk. The group almost entirely represented federally funded product development. Robert Lee heads the Untvac Government Computer Security Committee at Arden Hills in St. Paul, However, he was unable to attend the meeting. The meeting consisted mostly of my presentation on threats to computers.

Univac is developing a new computer based on virtual machine concepts for NTDS to be delivered soon to NELC. These concepts have isolation of users and data as a basts thus assuring significant levels of security. At the NBS/ACN Workshop I learned that Clark Weigsman at SDC has received a major contract to assist IBM (Joel Birnbaum) at the Watson Research Center in Yorktown Heights on development of virtual machine concepts.

The Univac people stressed the importance of recovery and minimizing false alarms, as well as prevention, detection, and deterrence when considering aspects of computer security.

This meeting was too brief and included too many people to be very effective. In any case they are now alvare of RISOS, I recommend meetings with Individuals such as Robert Lee mentioned above. 
Appendix B

REPORTS ON RESEARCH AND SERVICE ORGANIZATIONS VISITED 


\begin{abstract}
Appendix B
REPORTS ON RESEARCH AND SERVICE ORGANIZATIONS VISITED
\end{abstract}

As partial fulfullment of the SRI contract for Project RISOs at Lawrence Livermore Laboratory, Donn B. Parker visited the research and service organizations listed below.

MIT Project MAC, Cambridge, Massachusetts--Drs. Jerome Saltzer, Michael schroeder, Robert Scott (5 Januaxy 1973).

TRW Systems, Redondo Beach, California--Dr. Eldred Nelson

(9 February 1973).

TRW Credit Data, Garden Grove, California--Walter Thyer

(9 February I973).

Tymshare Corp, , Cipertino, California--Norman Hardy (22 January 1973).

Rohx Industries, Chula Vista, California (14 March 1973).

Reports of these visits are described by Mr. Parker in the following pages. 


\section{MIT PROJECT MAC}

On January 5, 1973, I visited Profs, Jerome Saltzer and Mike Schroeder at Project WAC and Mr. Robert Scott at the campus computing facilities at MIT.

Saltzer and Schroeder assume that the MuLICS ring structure has solved the controlled access problen in multiaccess systems except in one respect, its auditability. Their major efforts in solving this problem. will consist of reducing by an order of magnitude in size and complexity the 80,000 instructions and 400 modules of the security functions. They expect this will result in an isolated, simple package understanduble by one person and thus made auditable. They believe this is now possible with the MULICS ring structure hardware features, other systems such as RSs would require a reduction in complexity and siae by two orders of magnitude to do the same thing. Their plans include holding the functional capability of the system constant for now with passible trade-offs to improve cost-effectiveness Iater, A few nonparallel, dependent functions must be made parallel to simplify those functions. Expanding the types of interrupt processes can now be tolerated, and isolation of the security functions from the general operating system functions $w 111$ be accomplished. When I mentioned Dan Edward's statement that the only technique he is aware of that could stop $31 \mathrm{~m}$ from system penetration is compartmentalization, Saltzer indicated that some aspects of compartmentalization exist in NuLTICS but basic design would have to be redone to uchieve it fully. It is too late for that now. 
I suggested a hardware provision for back tracing of central processor control transfers as I had with John Weil at HIS. (I was told this idea was first reported by Van Korn.) They thought it sounded like a good idea and consistent with their auditability needs and a structured program approach.

A lengthly discussion was held on integrating security control in the central processor versus establishing control in a separate minicomputer-based device. They thought it might be a short range solution to the security problem in present systems. However, for new systems, integration directly into the hardware and software in the system as in MUTICS offers the lowest overhead and efficiency with adequate separation of functions.

The ring siructure design provides for distributed authorization control at the user level. In contrast, the IBM RSS design forces a centralized authorization in the person of a security officer and security terminal. In the HIT environment in CISS, a centralized authorization control proved to be painfully cumbersome to the degree that it was a negative factor in security. Users found it was too much trouble to stablish authorized access to their files aJd programs and handled in problem in informal ways, thus eliminating any system protection. Every organization will have a different configuratin of authorization control based on their cepartmental, project, and work confidentiality makeup. This makes a strictly dispersed authorization control or a strictly centralized control impractical. I was assured that MULTICS will provide a tree structure of authorization control to fit any user organization, al though the details of how this is accomplished were not described to me. It is also unknown what the system pays for this flexibility. A study of this sulject may be desirable to see what computer systems could provide and what various types of user organizations require. 
Bob scott in the campus facility that is studying and testing ass reiterated this point. RSS lacks flexibility to shape the security and operating system functions to the ever-changing needs of the organization it is serving. This is doubly inportant in security matters where modification of the system security softuare is so dangerous. Bob also pointed out that RSS and IBM OS in general make establishing of files difficult and establishing access authorization doubly difficult, leading to a negative security factor because users won't bother with protective features. Bob emphasized the need for flexibility and ease of use. 
A meeting was held at TRli Systems with Dr. Eldred Nelson; Jerry Short, IBM RSS Evaluation Project Manager; and Frank Stepezyk also from that project. At Credit Data, a meeting was held with manager Walter Thyer, Director of the National Data Center; Paul Palermo, manager of Network Analysis; and Leonard Eckhaus, Operations Manager.

TRW Systems is working under contract to IBM on evaluation of the Resource Security System. It is developing security requirements and security software certification methods. Tools to aid ir testing such as the TRW Product Assurance Confidence Evaluator (PACE), developed and reported on by J. R. Brown and R. H. Hoifman in the AFIPS FJCC, 1972 Proceedings, are being used. IBM is to supply TRW with an extensive set of software tools used internally by IBM. TRW claims great success in reducing software bugs by using testing tools such as PACE. No structured programming methods were used in the software tested by these tools,

Certification of software methods is being modeled on methods used by the Federal Aviation Agency to certify aircraft. Certification methods development is restricted by limiting approaches to those that are politically acceptable rather than just technically sound. Sortware development is looked at in four phases: design, implementation, certification, and recertification. Stepczyk indicates that although TRW has identified generic classifications of system penetration methods, this does not help in secure system design.

Dr. Nelson supplied information about a computer-related criminal activity which $I$ have documented elsewhere. 
At Credit Data, Thyer, Palermo, and Eckhaus said they could not discuss individual unauthorized acts or threats because of the sensitive mature of their business. However, apparently there have been many problems ranging from bomb threats to theft of credit information. They suggested I talk with Ray Hilliams, head of TRH Security, and Tony Fortuna, public Relations for TRW. They showed me a typical threat letter that was highly irrational. The Garden Grove national network facility is located in an obscure, unmarked building behind a branch bank in Garden Grove near Disneyland. Identilogic door control devices are used, but they find the use of card keys too cumbersome and are converting to combination, pusb-button locks. About 80 girls are employed there to answer telephoned credit inquixies by using CRT terminals running on-line to a large IBM 360 installation in the next room. They do not plan to use RSS but are particlpating in the RSS study. They rely totally on customer identification numbers to identify authorized sources for information requests. They do extensive non-real-time analysis of activity logs for such detection functions as skip tracing-pattern analysts of sources of credit inquiries regarding an individual as indication of a possible fraud.

Credit Data is not particularly advanced in computer security. However, 1 is working hard to accomplish better security with limited funding. It is concentrating on security involving their employees such as sqreening and separation of responsibilities. One suggestion conding out of the discussion was the need to establish the cost of security as a separate line item in the budget to assure proper attention by managenent. There is much lip service to security but little is done in financial support. 
TYMSHARE

I Interviewed Norman Hardy, Howard Steadman, Ray Wakeman, and James Fonda at Tymshare's Technical Division tn Cupertino, California on January 22, 1973.

Security and reliability are two highly interrelated concerns at Tymshare. When reliability fails, it must be assumed that security does also. Norm Hardy is aware of some of the techniques of systam penetration used by Dan Edwards at NSA. He claims these specific tectniques would not work in penetrating the Tymshare system. However, the level of effort and skill applied in these examples would most likely result in penetration of the Tymshare systen in other ways. Tymshare belleves this level of effort could include telephone circuit tapping, and this has created interest in cryptography and protection in message switching activity. A scrambling program is avallable to customers for protecting files stored in the system. Many Tymshare customers use it. It is also possible for customers to replace Tymshare protective features with their own to change the level of protection. However, protection by holding the algorithms confidential would result in a false sense of security. Confidentiality of protection methods is probably a motivation for doing this anyway.

Tymshare prints the last LOGON date and time for each user at LOGON, This provides a certain amount of protection from theft of services, It vas interested in the poaching bit technique used at Stanford. Backup files are dumped on tape once each week and stored remotely. Changed files are dumped on tape dally. Tape handling represents a hazard because it requires real-timc operator decisions and actions involving customer and system illes. Tymslare is looking at bulk storage devices to replace 
most tape usage with one of the benefits being automation of security (minimizing real-time involvement). There is a continuing concern for how much the operations staff should be aware of technical aspects of the system. Norm thought that the operators are bonded.

Jim Fonda had direct knowledge of system penetration activity among other time-sharing companies. In 1969 a consitierable amount of accessing was going on between two firms that were supposed to be sharing their technology but were not doing so to the extent agreed on. This resulted in 2 desire to penetrate each other's systems to check on this. Each knew the other's system making it relatively easy to penetrate. During this period, Tymshare was also penetrated by at least one of these firms. Penetration started with discovery of privileged commands by trial and exror. Tymshare error messages helped by informing the user a comnand was legttimate but that the user did not have high enough privilege status to use it. Penetration required about a month and a half, about 40 hours of terminal time, and a total cost of about $\$ 1,000$ in terminal service and telephone charges. When Jim came to work for Tymshare in charge of quality control, he assisted In changing the system to prevent the attack methods used.

The ethics of penetrating competitors' computer systems was discussed at length. One positior. holds that once a user has legitimate access to a system, anything he can find or do 1 s legitimate in the absence of any limiting contractual agreements or official notices to the contrary. The ISD versus UCC case is the only legal precedent being set and covers only cases involving unauthorized Locons. There are no accepted industrywide standards, customs, or practices. It is clear that action by trade associations and individual service companies is much needed. Controlled access must be accompanied by "no trespassing" slgns. 
HOHR INDUSTRIES

This report is based on a visit to Rohr in Chula Vista (neay San Diego) for discussions with Tom Bernard, Director Robrdata Systems; and Harry Goodel1, V1ce President of Management Systems and Controls.

Rohr has one of the most advanced on-line comput: systems for manufacturing control; 160,000 kinds of parts are manufactured, inventoried, and shipped involving 30,000 shop orders per day through 20 departments requiring 50,000 transactions per day. The system consists of two IBM $360 / 65$ computers, 300 million characters of on-line disk storage and about 200 termigals. Two PD-9 computers on-line to the 66s control a completely automated parts warehouse. Most of the terminals consist of small Touch-Tone pads and voice-answer back speakers hardwired to multiplexers and served by Wavetek voice-answer-back equipment, Each terminal, the communication line, and its share of a multiplexer costs $\$ 22$ per month. The system tracks all parts, material, and labor through the entire manufacturing process. It greatly increased productivity, reduced inventories, and reduced staff. For example, the timekeeping staff was reduced from 60 to 15 people.

The system operated with 97 percent accuracy until about one year ago when a Iabor strike occurred. After the strike ended, accuracy dropped to 70 percent. The system accuracy is totally vulnerable to the accuracy of the $i$ nput by the workers and dispatchers. Sabotage was suspected but never actually proved. In any case, the solution to the problem requited strengthening the security and protection of the accuracy of the system, Several months' effort has brought the system back up to 97 percent accuracy and reduced the possible occurrence of intentional acts or unintentional errors and cheating. 
The strike did not Involve the automated tracking system. In fact, there is a general feeling of satisfaction and acceptance of the terminal system by the workers. Although they personify the system and the voice they hear, the workers still identify managers as the scurce of any pressure put on them and watchdogging and inconvenience. They are proud trat they "operate a computer" in their work and feel they operate it rather than it operating them. This attitude is partly supported by the AFIPS/Time survey on the public's attitudes toward computers and refutes the popularity of the "big brother" concern fostered by the public information media. The simple nature of the terminal and voice rather than printed output seems also to be factor in this attitude.

Increased accuracy and security of the system have been achieved in several ways. Editing and checking of the input includes adding check digits to numeric codes and identifiers, Crosschecking of related data is performed. For example, a worker's labor code input is checked with the part numbers of the material he says he is working with to make sure the material is at his work station or in transit. Labor distribution discrepancies are immediately checked by timekeepers who get exception reports at CRT and TTY terminals. Parts and material discrepancies are also handled on-line by a manufacturing control group through the dispatchers, There is additional inherent protection by the system, because the workers never know how much checking is actually going on. They are continually amazed at the ability of management (with the system) to discover errors and discrepancies. This helps keep potential saboteurs and cheaters off balance.

The system is far from foolproof, but continual checking and improving the detection mechanisms goes on. A new systems reliability group of eight systens analysts and programmers has been formed to formalize this process. 
Appendix C

\section{OTHER ACTIVITIES}

\section{Conferences attended}

1972 Joint Computer Conference, Anaheim, California.

ACM/NBS Workshop on Controlled Accessibility, Rancho Santa Fe, California.

IEE Computer society Compon73, San Francisco, California

International Conference on Computer Communications, Washington, D.C.

IEEE Computer Society Special Interest Workshop on Computer Security, Washingtion, D.C.

ACM Symposiun on Computers and Communications, San Jose, California.

\section{Cases Investigated}

Metridata, Louisville, Kentucky (Appendix of the Investigation Manual)

Schneider/PT\&T, Los Angeles, California (Report enclosed below)

ISD/UCC, Ward, Palo Alto, Oakland, San Jose, Californila (Appendix of the Investigation Manua1).

EDP training in prisons, Wellesley Hills, Massachusetts (Report enclosed below).

Los Angeles County Welfare fraud, Los Angeles, California.

Donn B. Parker's interview with Jerry Schneider is presented on the following pages, together with a discussion of the implications of EDP training in prisons. 
INTERVIEW WITH JERRY NEAL SCHNETDER

Shir Tokubo of Project RISOS at Lawrence Livermore Laboratory and I met with Jerry Neal Schneider for about two hours at the Airport Narina Hotel in Los Angeles on 16 October 1972. Also present was a frient of Jerry's, Bill wyland, an investor. He and Jerry recorded part of our conversation on television tape. Jerry claimed tt was for his own use and for promotional purposes. My interview with Jerry about his acts leading to his criminal conviction and his current business plans was the portion taped. He offered to make a copy of the tape for me.

Jerry is about 25 years ol d, and electronic engineer graduate from UCLA. He planued his theft of communications equipnent in a rational, methodical, purposeful manner. His mottves were financial gain, the challenge, and w strong hatred of Pacific Telephone Company because of its lack of concern for customers, the public, and other enterprises. He says he supports capitalistic enterprise otierwisa. He claims never to have been in trouble with the law previously. He said he would return a lost wallet to its owner and would not do a dishonest act resulfing in a loss to individual people. However, he volunteered that if hi: saw $\$ 10,000$ sitting unattended in a store and felt that he could take it without detection, he would and suggested any reasonable person would. He clatms the court-appointed psychiatrist tolit nim he was not a criminal type.

His methed of gaining the knowiedge to perretrate his acts wag quite straightforward. He claims to have posed as a writer doing an article on equipment-ordering systems and was given much information about the PT\&T RAMAC ordering system running on an IBM 360 computer in batch mode. He 
obtained flow diaglams and instructions for employees from a waste basket. He posed as an employee of other companies and of pacific Telephone in calls made to the company's RALAC staff asking them detailed questions about input formats, equipment codes, and delivery sice codes. He obtained the account numbers and passwords to access a conrtercial time-sharing service used by PT\&T. The access codes were changed three times, but the new ones were given in Pacific Telephone's news sexvice to customers using the old codes. He claims that he was able to run PTBT programs using its data files to get inventory control and distribution analysis information. It was not clear that he also changed data to account for equipment he stole. He formed the Los Angeles Telephone Company and at least some of his staff knew he was stealing from PT\&T. He would telephone into PT\&T and order equipment from PT\&T staff for delivery at PT\&T field sites. The orders were punched on cards and ordering was carried out in batch mode through the RAlHAC system. He then went to the sites at about 5 a.m. in a truck that looked like a Pacific Telephone truck and picked up the equipment and bill of lading so that none of the site people knew of missing equipment or of equipment ordered. He insists that nobody within PT\&T was in collusion with him. He received all the information he needed from volunteered sources.

He had trouble with his staff because of complaints of low salaries. One employee attempted to blackmail him; when that failed, the employee reported him to the police. He claims the newpaper stories of his acts are almost all fiction.

Jerry has gone into business as a "special agent" in a firm he calls Security Analysts, security consultants in EDP, THX, P.L, SH. Net. His offices are at 1888 Century Park East, Suite 10, Century City, Los Angeles, California 90067, telephone (213) 277-3266. He claims to offer security consulting services to help firms, especially telephone 
companies, to avold attacks such as he made on Pacific Telephone. He claims PT\&T will not do business with him, but he hopes to get a contract wi th AT\&T in New York City to write a report on what he did and how it can be prevented. His method of prevention is to develop EDP security staff who would check all company EDP activities and maintain a responstble security attitude among the EDP staff. He does seem to have thought this out very clearly but has much to learn about EDP security and management principles of security. He claims to have an appointment with the Chief of Security for AT\&T in New York, to propose his plan, He is also willing to sell his repr:t to others and says he is flanning to write a book. He also claims to be negotrating with Gerald sicknight, an English author who is writing a book on computer security and with whom I also have had some contact.

This encounter with Jerry adds support to my hypothesis that a security system must take into account that the perpetrator will know sufficient methads of access to the system and will know most of the detailed specifications of the computer applications, operating system, hardware, and security methods used. Also it supports the idea that automation of security to eliminate humans from security processes as much as possible and development of pattern and tolerance analysis in the system to detect anomalous actions are among the most important areas of development for increasing security effectiveness. 
THE IMPLICATIONS OF EDP TRAINING IN PRISONS

This report is in partial fulfuliment of an SRI subcontiact with Project RISOS at Lawrence Livermore Laboratory. It is based on previous investigation, a visit with Kurt Van Vlandren and italcolm Smith of Honeywell in Wellesley lills, and telephone conversations with William Perrin, a consultant and former director of an EDP education program for the Department of Corrections, State of North Carolina; and Kenneth Thompson, who organized a similar program at Southern Michigan Prison,

This short, preliminary investigation is part of an effort to determine the population of potential perpetrators of unauthorized penetration of computer systems. This population must consist mostly of people with the necessary technical skills, knowledge, and access. My initial conclusion is that EDP cour'ses in prisons demonstrate that professional criminals have an opportunity to acquire the necessary skills, knowledge, and access, However, this source of potential perpetrators is insignificant compared with the many, more successful, professional and whitecollar criminals with opportunities for EDP education in high schools, trade schools, inservice training programs, colleges, and universities, Most of the EDP training of convicts occurs in state prisons where innate students, wost of them with underprivileged backgrounds are convicted of violent crimes rather than crimes in which EDP training could be helpful.

William Perı in found 26 states with prison EDP training programs in 1969. Only a small number of prisoners are trained because of heavy screening and aptitude restrictions. The program at Walpole prison supported by Honeywell has resulted in 63 paroled graduates in five 
and one-half years with about one-third known to have entered the EDP field. While general rates of recidivism among state prisons are 60 to 70 percent, recidivism among the IDP program graduates is less than 6 percent in Massachusetts and North Carolina. Graduates tend to get jobs in government organizations where they had obtained in-prison wolk previaus to paxole. Prisoners form companies while in prison to parform work on outside contracts, Courses are often vaught by more advanced inmate students. Courses cover programning languages, business matheratics and administration, hardware maintenance, systems analysis, and occasionally advanced systems programming. Of 20 recent graduates from Walpole, Honeywell employs three, DEC has one, the State Department of Education has one, and the City of Newtou Education staff has one. One graduate, over 50 years old, spent most of his life in prison; he never held a job for more than a day during years of freedom and was almost a living vegetable in prison. Programing sparked 11 fe $1 \pi t o \mathrm{hlm}$, and he is now a successful systems programmer with a computer manufacturer.

Ex-convicts are normally hired in EDP with full knowledge and cooperation of the employers. An employex with strong management, adequate security, including separation of sensitive responsibilities, should have no qualms about hiring an ex-con. His background will always be well known. He lives under strict personal performance rules while on parole, and a good-paying job which he has probably never had before creates an environment in which he is probably highly motivated to make good. He also knows that if any unauthorized actions occur in his working facilities, he will be the first to te blamed. He may be torn by two conflicting forces if confronted by such a situation, Cooperation in apprehending the perpetrator keeps his reputation clean and improves bis chances, but the unvritten law among convicts and ex-convicts forbidding "ratting" may be more influential. Ex-convicts are prime targets for extortion and influence by former criminal associates 
possibly forcting them to perpetrate vnauthorized acts. This must be particularly puarded against. Nonetbel:ss, the fact that they are "known quantities" makes them attractive potential employees when hired in small numbers for rehabilitation purposes

Among 100 cases of computer-related acts none has yet been discovered to have been committed by ex-convicts. 
Appendix D

QUESTIOMNAIRE FOR DOCUNEMTING COIPUTER-RELATED INCIDENTS OF INTEMT LORALLY CAUSED LOSSES, INJURIES AXD DAZLGEE 
Part 1. Case ID

Earliest Date of Act

Date of This Report

Revised Date

COMPUTER-RELATED MCIDEIT QUESTIONRATRE

PART 1. CASE DEENTIFICATION

2.2 Case name

1.2 Brief case description

1.3 Key words extracted from 1,2

1.4 Names of computer systems 1nvolved (operating organization and generic tyge)

2.5 Case locations. Cities and local sites of acts, targets, perpetrators

2.6 Participants. Victias, suspected perpetrators, prosecutors, witriesses

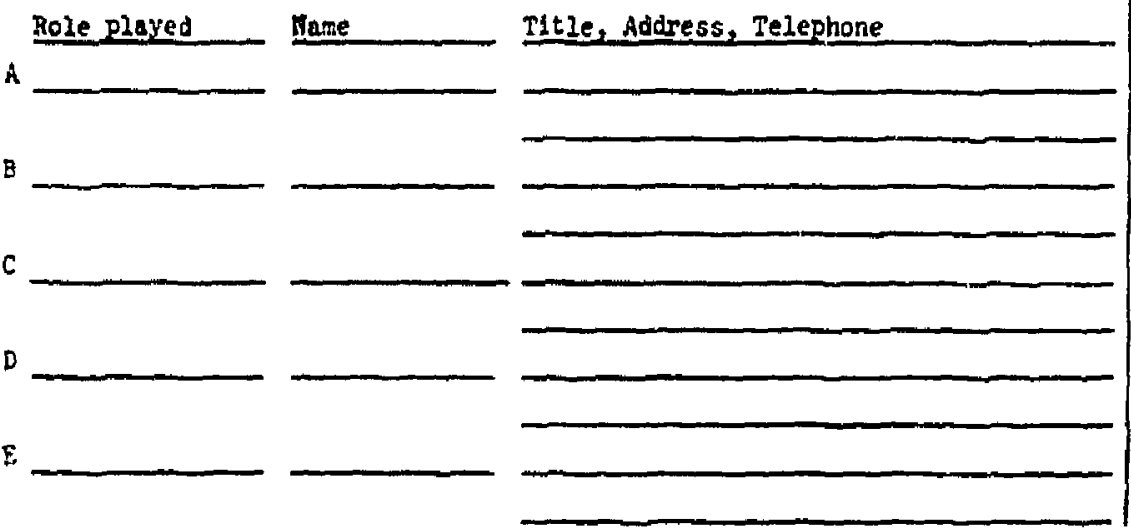


1.7 Type of investigation and sources. Identify all applicable items by inserting names of sources and dates

On-site investigation

Telephone calls

Letter correspondence

Face-to-face interview

Directly quoted

Docusent extraction

1.8 Authors of this questionnaire

Revision by

1.9 Case Investigators

1.10 Case documents

Location

\section{Dates}

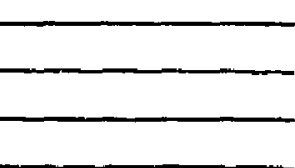

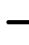
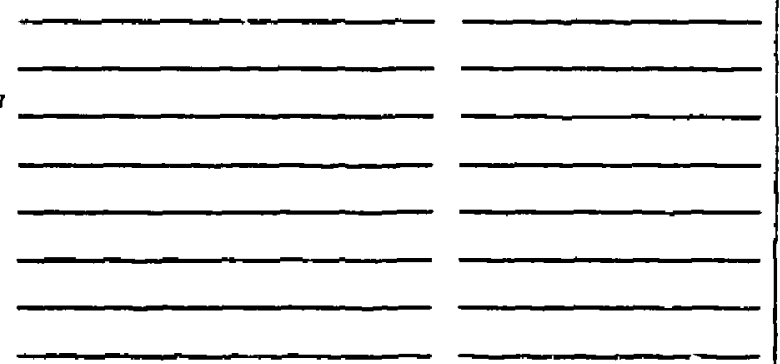

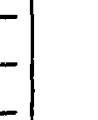
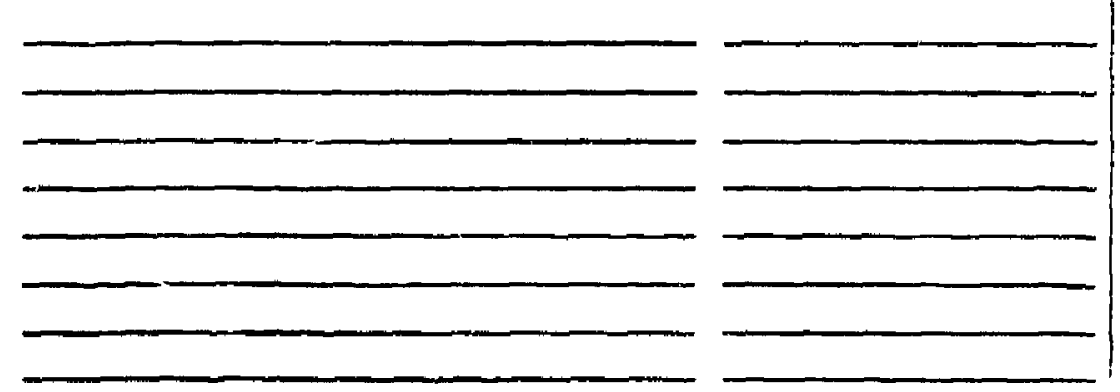
COMPUTER-RELATED TNCIDENT QUESTIONNAIRE

PART 2. ENVIRONMENTS OF THE ACT

2.1 Computer systems involved in the case. (Use one form for each system)

2.1.1 System identification

\section{Operating} organization

Facility Locetions

\section{CPU Vendor,} Model, Storage

Mode of Operation

Purposes

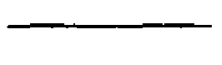

2.1.2 Peripherals pertinent to the case

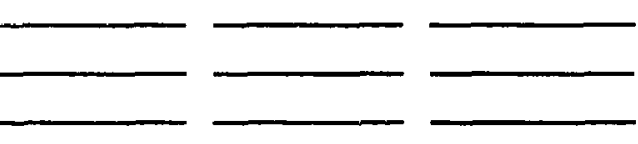

2.1.3 Operating system, options, modifications, edd-ons

2.1.4 Software packages pertinent to the case

\subsubsection{Terminels pertinent to the case}

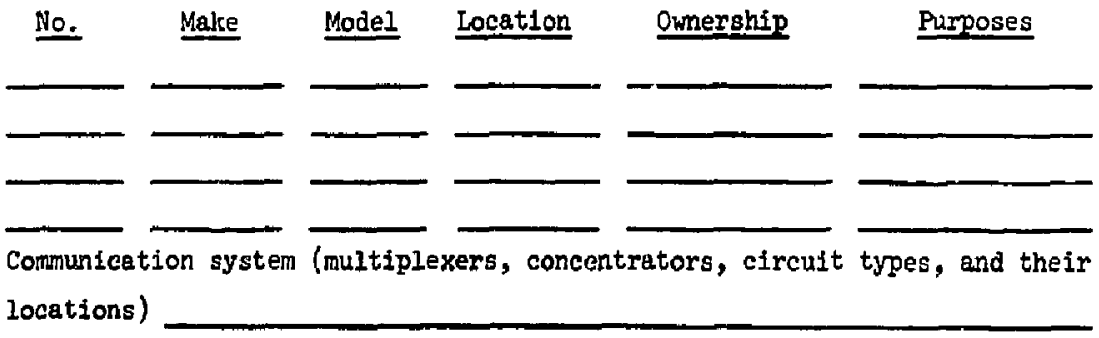

2.1.6 Communication system (multiplexers, concentrators, circuit types, and their locations)

2.1.7 Type of computer system application. (C1zcle letters. More than one type may apply at differant times) a. Transaction system. b. More than one transaction subsystem. c. Transaction subsystems and programer access. d. Programmer access at agplication language level. e. Programer access at machine language level, $f$, other 
2.1.8 Type of access authorization control. (Circle letters, More than one type may apply at different times.) a. None. b. Centralized authority granting. c. More than one can grant authority. d. Individual users can authorize others. e. Other

1.1.9 Security levels present. (Circle letters. More than one type mey apply at different times.) a. System and contents open to all users. b. Part of system and/or contents requires authorized access and part is open to general access. c. More then one level of authorized access in addition to general access. d. More than one level of authorized access and no part is open to general access. e. All access must be authorizeri. f. Other

2.1.10 Degrees of confidentiality of the contents of the system. (Circle all appropriate letters.) a. U.S. Government classified (national security). b. Personal or organizational safety (compromise wolld cause personal unrecoverable injury or death or organizational failure). c. Personal or organirational integrity (unrecoverable injury, damage or loss).

a. Personal or organizetional Iecoverability (recoverable injury, demage or 1oss). e. Personal or organizationel convenience (irritational injury, damage or loss), $f$, Public domain (no confidentiality). g. Other

2.1.11 Number of employees dedicated exclusively to computer system protection (Supply numbers). EDP auditors a. Guards b. Data validation/ control clerks $c$. other $d$.

2.1.12 Staff contacts (operations, systems, applications, hardware maintenance, EDP audit, security) 
2.2 "Quick-check" aystem characterlstics (Use one set for each system) System identification

(Circle appropriate numbers)

1. Local betch

2. Reruote batch

3. Time-sharing

4. Multiaccess

5. Time-slicing

6. Multiprogramned

7. Multiprocessors

8. Single mode of operation

9. Multimode, simultaneous

10. Multimode, sequential

11. Network-connected

12. Hierarchically-connected, head end

13. Hierarchically-connected, sibsystem 14. Date communications used

15. Multiplexers on-site

If. Remote Multiplexers

17. Concentrators on-site

18. Remote concentrators

19. High speed circuits ( $\$ 9600 \mathrm{bps})$

20. Low speed circuits (<9600 bps)

21. Dial-up circuits

22. Privete circuits

23. Lessed circuits

24. Microwave

25. Half duplex

26. Full duplex

27. Synchronous

28. Asynchronous

29. Conversational terminals

30. Sitch or job terminals

31. Transaction terminals

32. Grapinies terminals
33. Telemetry terminals

34. Real-time, process control terminals

35. Conversetinnal terminal response

36. Performance monitoring devices

37. Tape drives

30. Disis drives, permanent

39. Disk drives, removable

40. Magnetic drums

41. Add-on core storage

42. Paper tape

43. Mass storage, optical

4h. Multivendor central configuration

45. Paged storage, hardware

46. Paged storage, software

47. Virtiul storage, hardware

48. Virtual storage, softwere

49. Relocation feature

50. Hardware storage protection

52. Privileged instructions

52. Continuous operation

53. First shift only

54. Two shifts

55. Three shifts

56. Weekend, hollday operation

57. Dedicated to one (few) applications

58. Business applicetions

59. Englneering applications

60. Research applications

61. Integrated file applications

62. Process control applications

63. Transaction applications

64. U.S. Government classified processing 
65. All access local to system

66. Multiple customers (corporations)

67. Service burealu operation

68, Operation shaied with other companies

69. Operation by a service company

70. Maintenance by CPU vendor

71. Meintenance by independent service

72. Multivendor maintenance

73. In-house maintenance

74. CPU-vendor supplieâ operating system

75. Independent vendor operating system

76. In-house operating system

77. Modified vendor opereting system

78. More than one operating sysiem used

79. On-line user-program librery

80. On-line application files

81. Files encrypted

82. Data encryption optional

83. Deta commuication hardware encryptionlll. Real-time humen monitoring of

84. Data communication software encryption

85. Terminal identification by hardware

Terminal Iocon by

86. User ID

87. Password

88. Single-use pesisword

89. Account code

90. Site code

91. Dinlog wth user

92. Time linit

93. Error limit

94. Portable sey or cerd

95. Security features integrated in 05

96. Security features added on

97. Security features in isolated modules

98. Centralized eccess authorization
99. Decentrallzed access authorization

100, Os isolated from users

101. Users' jobs isolated fron each other

102. File access restricted by authorization

103. First write befor: read data protection

104. Storage erasure after use

105. I/O buffers, registers cleared after use

106. Access authorization data in files

107. Access authorization in file index tables

108. User access to assembly-level language

109. File activity tracing or auditing

110. Security monitoring of system l'se

112. Console dedicated to security runctions

Remote beck-up storage of

113. Operating system

114. Application prcgrams

115. Data files

116. Removable storage devices stored local to drives

117. Positive door access control to fecilities

118. Programmers' and operators' work areas separated 


\section{COMPUIER-REIATED TNCDDENT QUESTIONNAIRE}

PART 3. DESCRIPTION OF THE ACTS ARD DETECTION

3.1 Type of act. (Circle applicable letters)

a. Unquthorized use of the services of computer systems.

b. Uneuthorized sale of the services o: computer systems.

c. Unauthorized taking of information, conputer programs or property of copies thereof.

d. Direct finencial gain by taking negotiable instruments or transferring monetery credit.

e. Yandalism.

f. Other

3.2 Access and methods used to perpetrate the acts

3.2.1 Is physical access to the sites of the acts epplicable and pertinent to this case? yes no

3.2.2 Physical access: times and days

(Circle appropriate letters and prefix capital letters to identify suspects) _a: Covert access. _b. Overt access. _o. Authorized.

_. Unauthorized. __e, Assisted by athers. __. Tools or devices uses to gain entry. __. G. Observed by others. __ n. Inpersonation used.

i. Access reported to responsible persons. When?

j. Diversion tactics used. Describe

3.2.3 Were the sites of the acts protected by: (Circle appropriate letters) a. Locked doors. b. GLards. c. Electronic/optical devices. d. Not grotectej. Describe

3.2.4 Methods and devices used: (Circle appropriate numbers and prefix capital Ietters to identify suspects) 1. on-line. 2. Ofs-line.

3. Conversational terminal. __. Transaction terminal. __5. Job entry terminal. _6. Computer console. _ 7 . Security console.

3. Supervisory terminal. __ 9. Haintenance console, __ 10. Direct manual action. ㄴ. Il. By issuing instructions to other people. 
12. Off-line program manipulation. manipulation. 14. Terminel commends.
13. Off-line job control

15. Imediate results.

16. Delayed results. _17. On-line program manipulation.

18. By imperâcnation. 19. Program impersonation. _-20. Uperating system penetration. _ll. Violation of program boundaries.

22. "ic?ution of data storage boundaries. 23. Violation of parameter value ranges. _-24. Sirulation of an aluthorized function.

25. Covert. 26. Overt. _27. New program. _28. Existing progrem. _29. Utility program. _30. Unauthorized use of identification codes. 31. Covert use of communicetion circuits.

32. Disgulsed as en accident, 33. Accident or error used.

34. Overloading of a system activity. _ 35. Overloading of a manual activity. 36. Diversion used. _37. Input date manipulation.

38. Output modification. __ 39. Subversion of protective features.

40. Procedural modification, 41. System breakdown (cresh) necessary for perpetration of the act. 42. Standard operating procedures used. 43. Non-standard operating procedures used. _-44. Information, programs or propercy taken from a person by force. 45. Information, programs or property taken from a person by deception. _46. Other

3.2.5 Narrative description of methods and devices used.

3.2.' Key words used above: 


\section{3 Goals, Targets and Results}

\subsubsection{Hardware}

1. CPJ

2. Storage

3. Channels

4. Controllers

5. Peripherals

6. Cebles

7. Terminals

8. Communicetions devices

9. Compunication cireuits

10. Parts inventory

12. Monitoring devices

12. Security devices

13. Other

\subsubsection{Media}

15. Disk packs

16. Magnetic tape (mini or cassette)

17. Paper tape

18. Punch cards

19. Film

20. Printer paper, carbon paper

21. Printer ribbons

22. Other

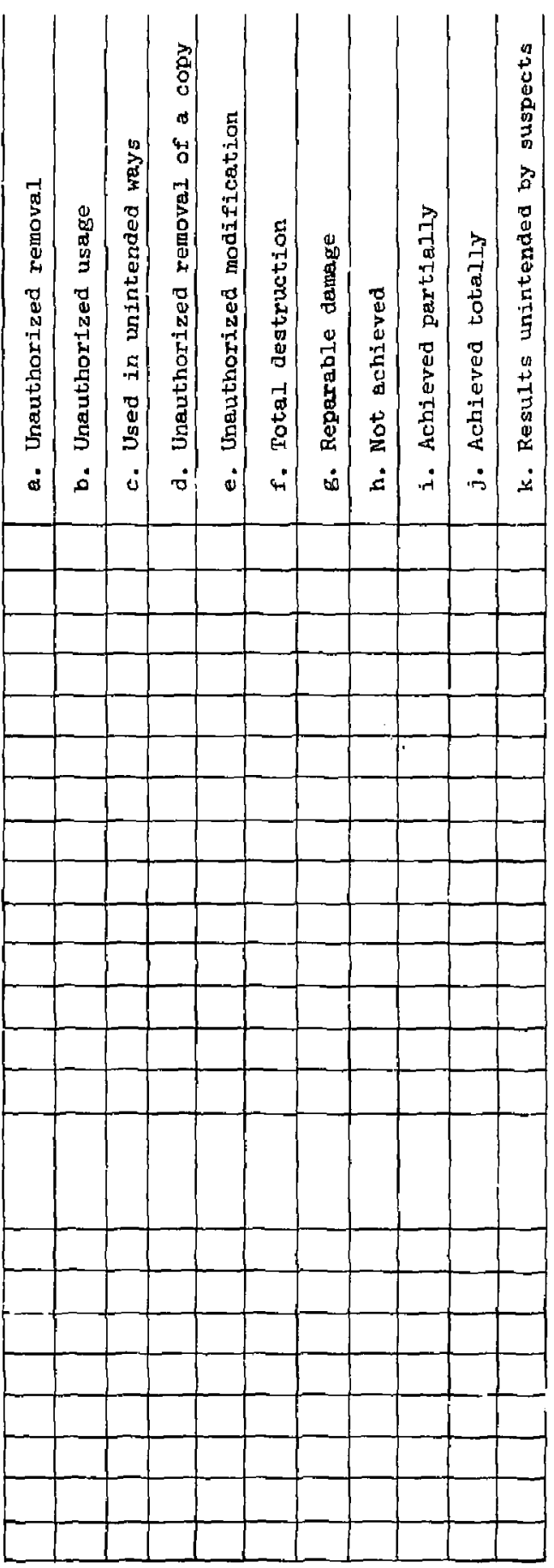




\subsection{3 software}

22. Application programs

23. System of application programs 24. Library of application programs 25. Job control instructions 26. Operating system

\section{Supervisor}

28. Job scheduler

29. Queueing contr I

30. Interrupt processor

31. Job swapper

32. Resource allocation

33. Storage manager

34. I/O processors

35. Operator control

36. Accounting

37. Recovery

38. System initialization

39. System bootstrap

40. Library manager

41. Job control transiator

42. Terminel manager

43. Activity monitor

44. Performance monitor

45. Access controller

46. Authorization controller

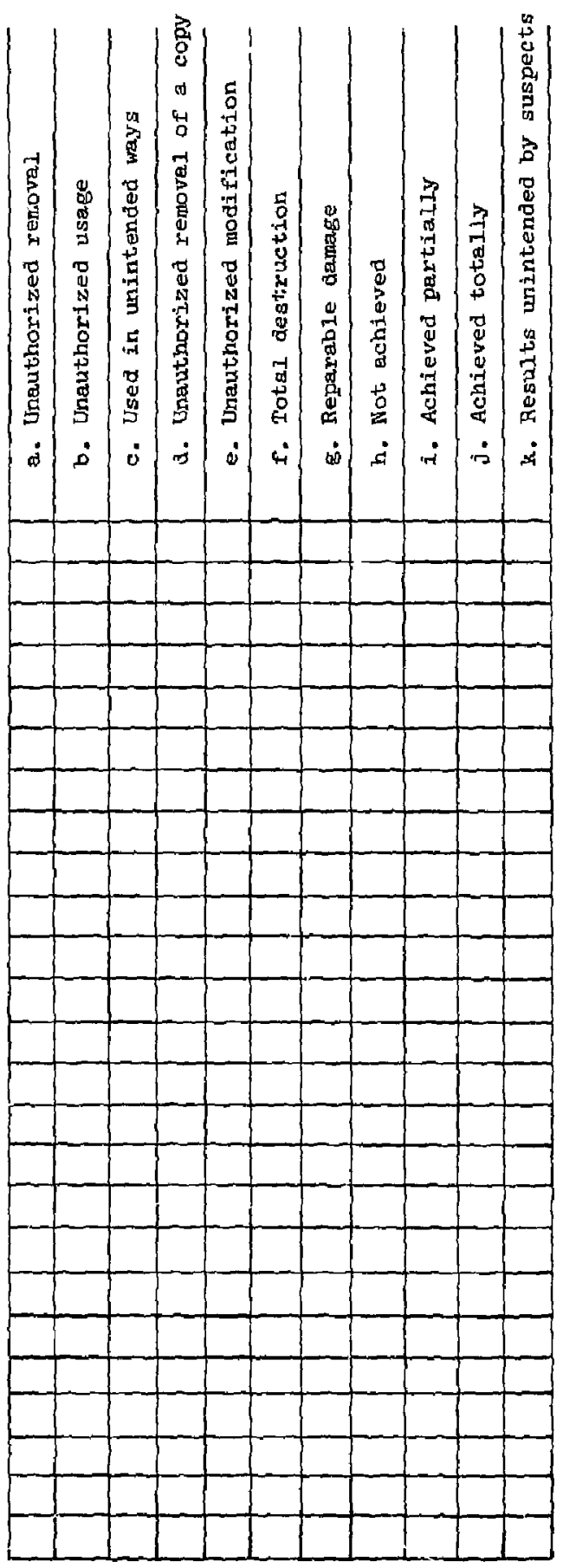


Case ID

47. I/0 drivers

48. Compilers, assemblers, trenslators

49. Utility prograns

50. Other

3.3.4 Data

51. Stored on-line application flles

52. Stored off-line application files

53. Machine-readable input date

54. Machine-readable output date

55. Input data for conversion

56. Output reports

57. Operations records

58. Active operating system tables, files

59. Security authorization tables

60. User identification tables

61. System monitoring files

62. Buffer filies

63. Queueing files

64. Other

3.3.5 Documents

65. System software manuels

66. System user mañuals

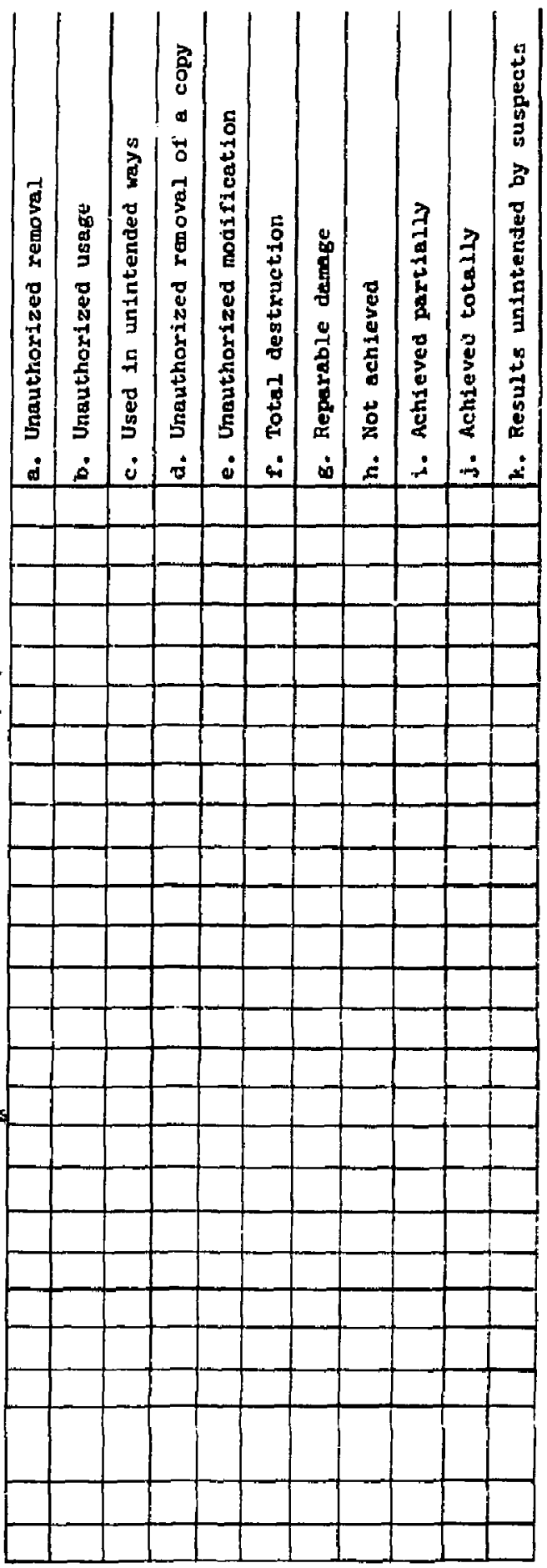


67. System softmre specifications

68. System desibn documents

69. System usage aids

70. System newsletsers

72. Hasnternence docunents

72. Herivere inenuals

73. Hardware drawngs

7h. Operator instructions

75. System stalus reports

76. Data control instructions

77. Audit documents

78. Securlty docunents

79. Data preperation Instructions

80. Application sapusis

81. Application spted fications

82. Organizacion procedures, ehcrts

83. Personnel lists

84. Published reports, papers

85. Linpublished reports, papers

86. Other

\subsubsection{Facilitieg}

86. Doors

87. Windows

88. Wells

B9. Floors

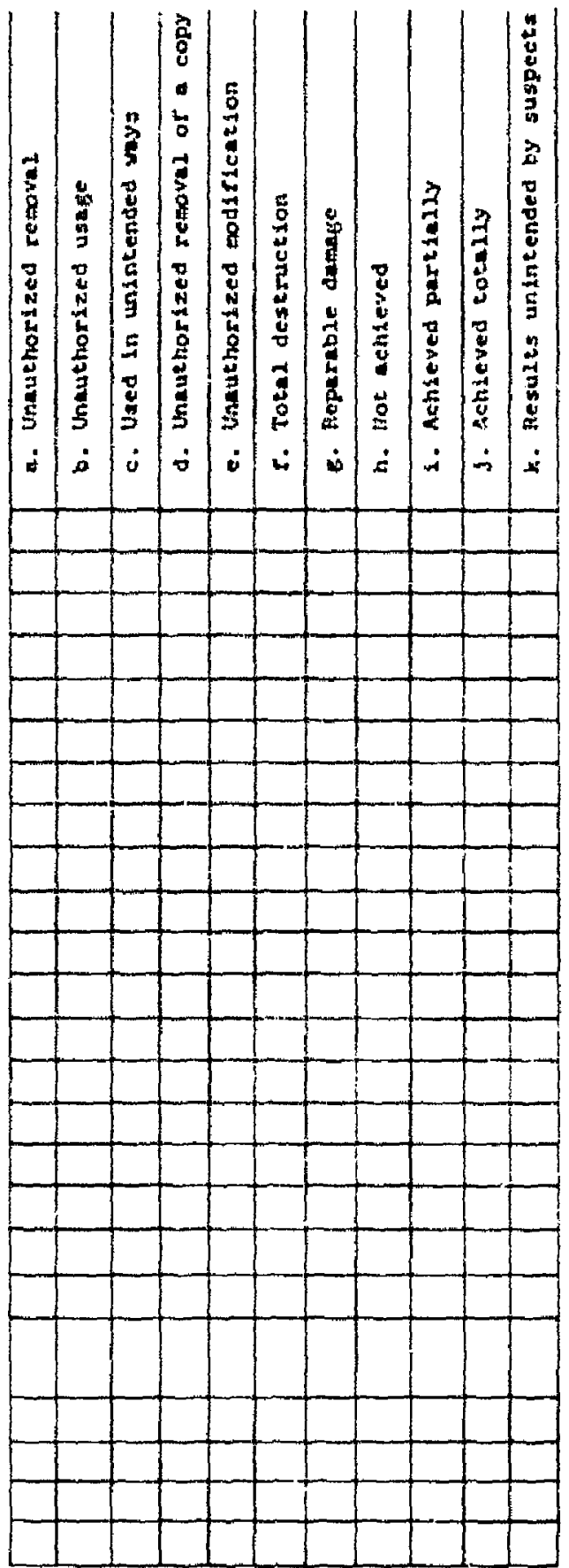


Case ID

90. Cetlings

91. Locks

92. Sufety equipment

93. Power supply

94. Oral comrunication equipment

95. Als conditloning equipment

96. Wights

97. Securtty alarms

98. IV equipoent

99. Photographic equipment

100. Furniture

101. Furnishings

102. Data keying devices

103. off-line processors

104. Other

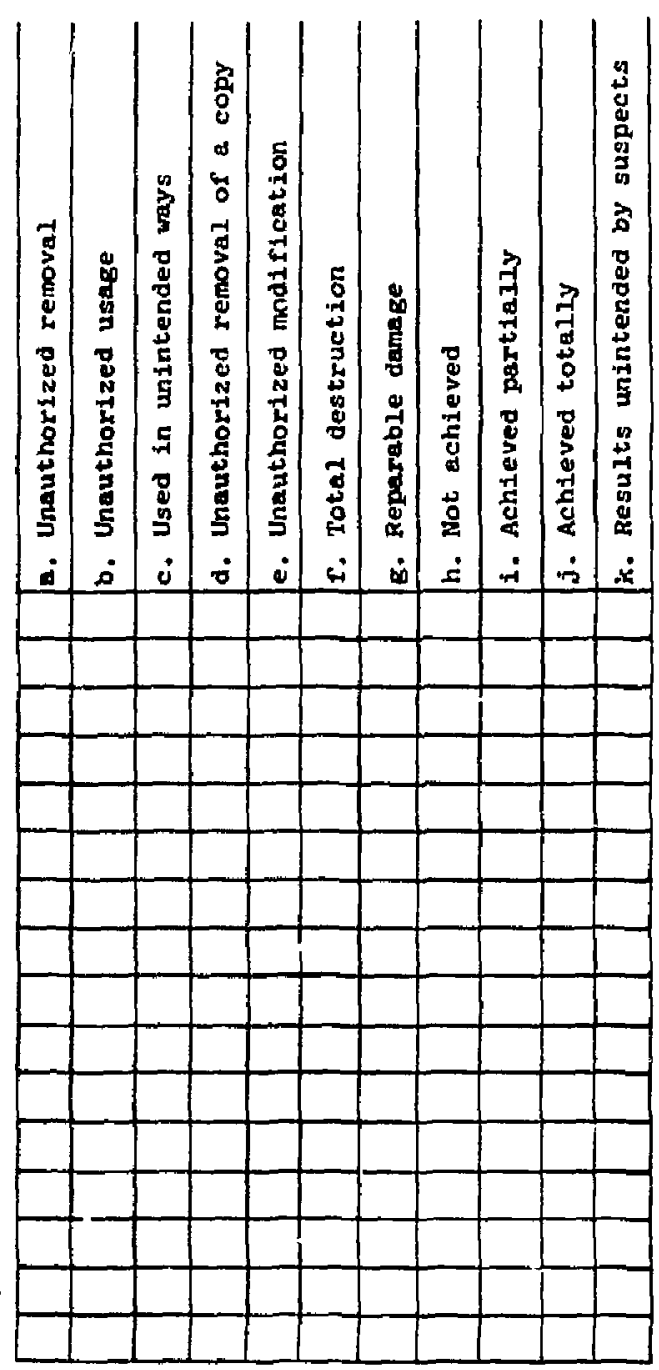


3.4 Actions taken by suspects to avold detection (Insert capital letcers to identify participants).

1. System logs

2. Security 108

3. Program changes

4. Data changes

5. Label or name changes

6. Prograns

7. Data

8. Buffer contents

9. Storage contents

10. Fingerprints, pictures

11. Waste materials

12. :Hoved equipment

13. Hoved media

14. Moved materials

15. Telephone circuit usage $\log$ 26. Other

17.

\begin{tabular}{|c|c|c|c|c|}
\hline $\begin{array}{c}\text { Restore } \\
\text { B. }\end{array}$ & $\begin{array}{c}\text { Change } \\
\text { b. }\end{array}$ & $\begin{array}{c}\text { Jestroy } \\
\text { c. }\end{array}$ & $\begin{array}{c}\text { Remove } \\
\text { d. }\end{array}$ & $\begin{array}{c}\text { Detributed } \\
\text { to } \\
\text { e. }\end{array}$ \\
\hline & & & & \\
\hline & & & & \\
\hline & & & & \\
\hline & & & & \\
\hline & & & & \\
\hline & & & & \\
\hline & & & & \\
\hline & & & & \\
\hline & & & & \\
\hline & & & & \\
\hline & & & & \\
\hline & & & & \\
\hline
\end{tabular}

\subsubsection{Describe}

3.4.2 Detection. (Circle appropriate letters) a. Before acts could occur.

b. During acts. c. After acts, time period

d. Accidental discovery. e. By establiahed detection methods.

f. Suspects identified. $g$. Suspects caught. 
3.4.3 Participants in detection and suspect identification. (Use capital letters to ldentify participants.)

1. Computer operations staff

2. Security staff

3. Audit sterf

4. Systems programning staff

5. Hardware taintenance scaff

6. Applications staff

7. Janitorial steff

8. Vendor's stafr

9. System users

10. Customer support staff

11. Other

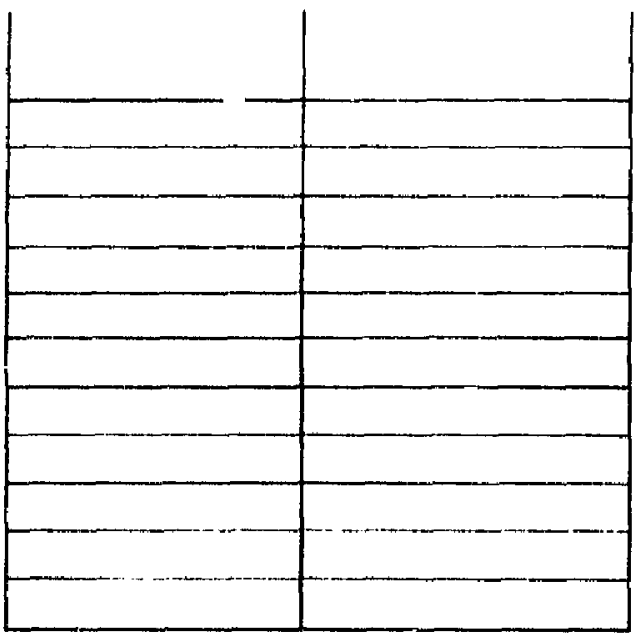

\subsubsection{Describe detection}

3.5 Suspects' positions relative to the acts and systems involved, (Circle appropriate numbers and prefix capital letters to ldentify suspects.)

1. Computer system management, ___. Company management, __ 3. Application programner/analyst. _4. System designer. _ 5. System programer/ anaiyst. _6. Program maintenance. _ 7. Auditor. _ 8. Data clerk. 9. Security guard. _30. Building maintenance worker. __ 11. Hardware maintenance engineer. _ 12. Data conversion operator.

13. Conputer/peripheral operator. _14. Courter or messenger.

15. Outside consultant. - 36 . Company employee (not in computer system staffl. _. 17. Vendor's employee, on-site. _ 18. Vendor's employee, off-site. _ 19. Internal customer of system. _ 20. External customer of system. _-_2?. Business competitor's employee. __22. Business associate employee. __23. A person involunterily served or affected by the computer system. _24. A person voluntarily served or affected by the computer system. _ـ 25. Sociaz or political dissident. __ 26. Other 27. Other 
3.5.1 knowledge and experience of the suspects. (Identify each suspect by a capital letter. Multiple entries for a single hox are acceptable.)

1. Access to facilities

2. Operation of teminals

3. Operation of peripherals

4. Operation of communications

5. Operation of computer

6. Job submission

7. Access identification

8. Data subinission

9. Data p:eparation

10. Data conversion

11. Data control

12. Application program use

13. Application program modiflcation

14. Applicetion programing

15. Systems programming

16. Operating system modification

17. Computer modification

18. Peripherals modification

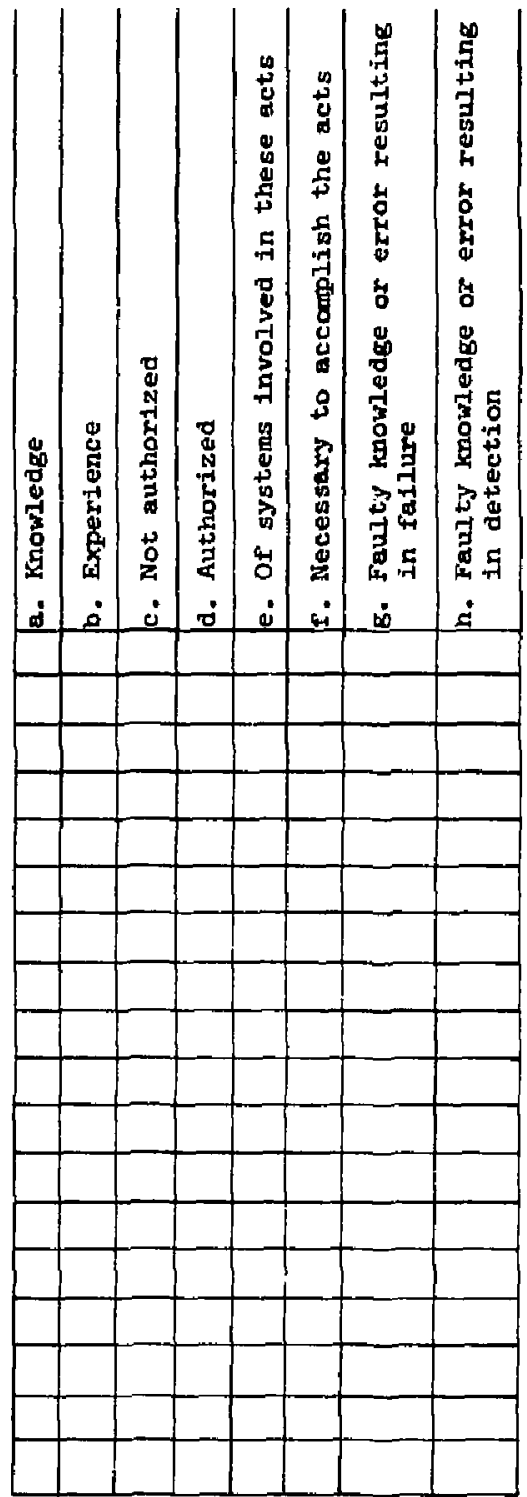


19. Terminals modification

20. Communication mod1fication

21. Wiretapping

22. Radiation p1ckup

23. System security modifieation

24. System auditing

25. Sys tem testing

26. Acquainted with staff

27. Acquainted with users/customers

28. Organization procedures

29. Stsff working schedules

30. System schedules

31. Independent troining course

32. Interpal training course

33. Other

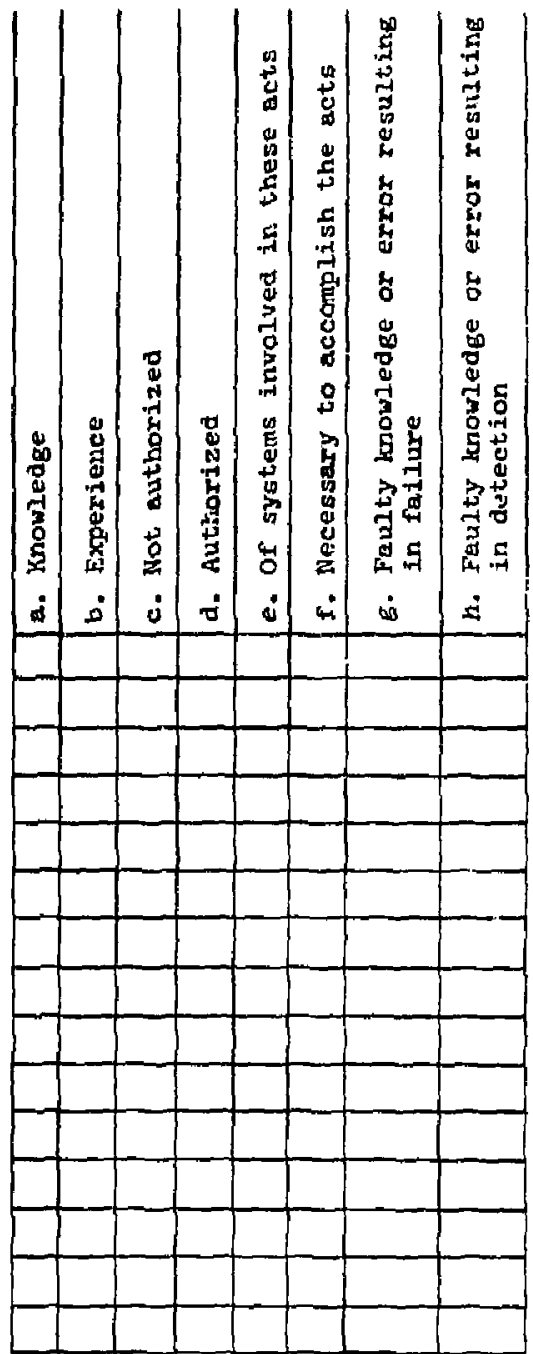

3.6 Estimate of value of losses, injuries and damages: $\$$

3.7 Changes made in the computer system as a result of these acts. Security increased? yes no Describe 
3.8 Most 1mportant implicetions of this case

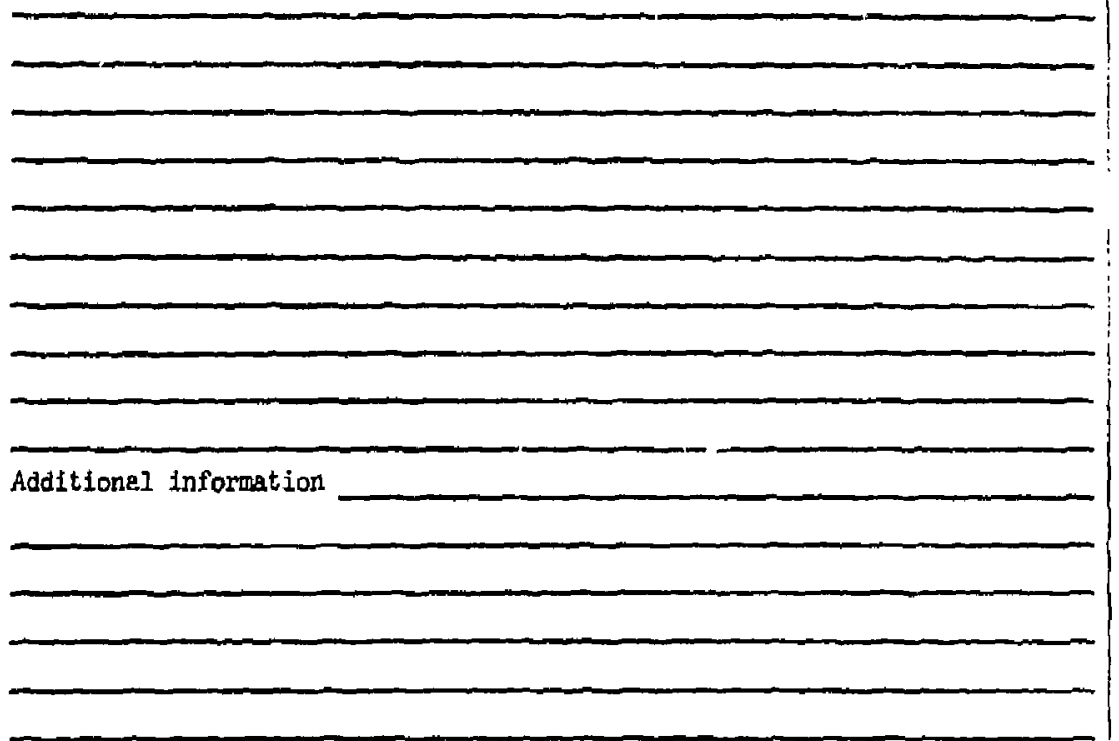


COMSIJER-RELATED THC IDENT QUESTIONNAIRE

PART 4. SUSPECT INVESTICATION (One form for each Stspect)

4.2 Interviews

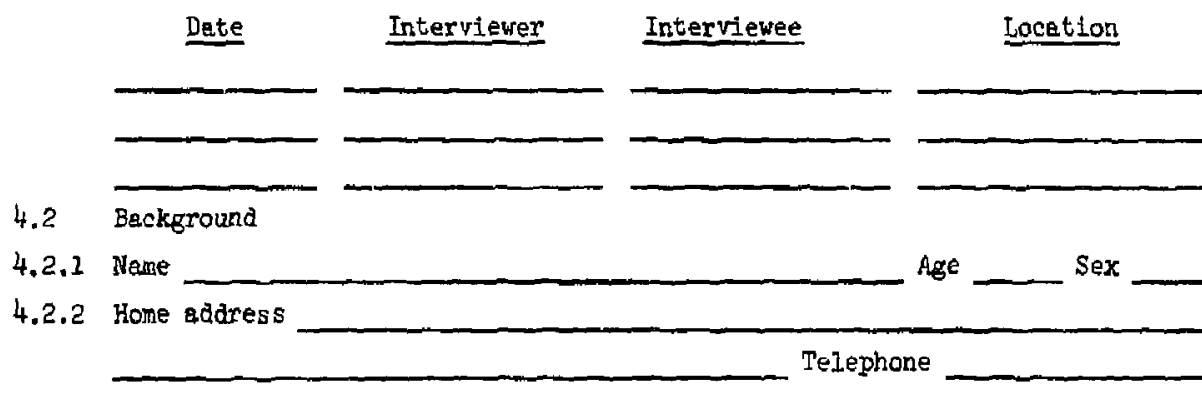

\subsubsection{Work address}

Telephone

4.2.4 Education (Circle) High school 1234 jears. Iocation College $1 \quad 2 \quad 34$ years. Locations

Degree Subject $\quad$ Institution

Professione: society membership

4.2.5 (Circle appropriate letters) a. Married b. Separated c. Divorced d. Widowed e. Single Children: Age _ Age _ Age ${ }^{\text {Age }}{ }_{\text {Years }}$
Present enployer occupation or title Brief job description

4.2.7 Other business interests

4.2.8 Salary (Circle a letter) a. less than $\$ 6000$ b. $6000-7999$ c. $8000-9999$ d. $10,000-13,999$ e. $14,000-17,999$ f. $18,000-23,999$ b. 24,000-29,999

h. 30,000-39,999 h. 40,000-49,999 i. More than 50,000

4.2.9 Recent employment (Most recent first) Employer

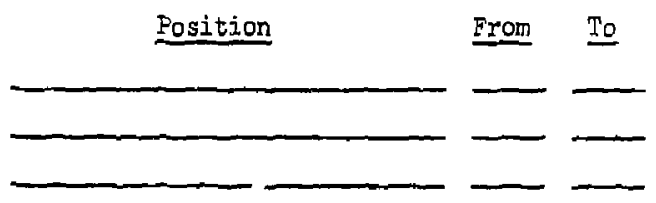


4.2.10 Criminal history. Number of arrests Arrest Charges
Number of convictions Disposition

4.3 Suspect's involve"ent in the incident.

Date

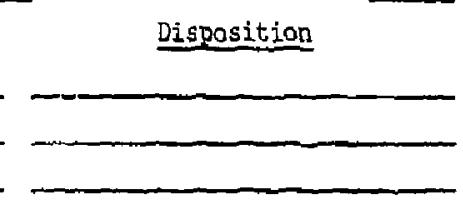

(a)

\subsection{Before the ects}

4.4.1 Purpose of the acts (Circle appropriate letters). a. Direct financial gein by acquiring a negotiable instrument or transfer of credit. $b$. Indirect financial gain by converting results of the acts to financial gain.

c. Personal advencement. d. Revenge. e. To support ideals. $f$. To right a wrong, 5. A challenge, h. Curiosity, i. Self-amusement. $j$. Amusement of others. $k$. To help somebody else. 1 . Other

4.4.2 Source of the 1dea for perpetrating the acts. (Circle appropriate letters.) a. Accident or error denonstrated the possiblitities. b. Learned of similar acts. c. Had perfarmed slmiler acts. d. Associates or friends performed similar acts. e. Associates or friends talked about similar acts. f. Exposure of the target represented a temptation. B. Apparent ease of the acts represented a temptation. h. Other

4.4.3 Attitude of the suspect towards potential individuel, personel victims, if any. (circle appropriate lettexs) a. Sorry, b. Symathetic, $c$. Hostile. d. Superior to them. e. Inferior to them. f. Indifferent. g. other

\subsubsection{Other similar acts suspect was aware of.}

Act

Source

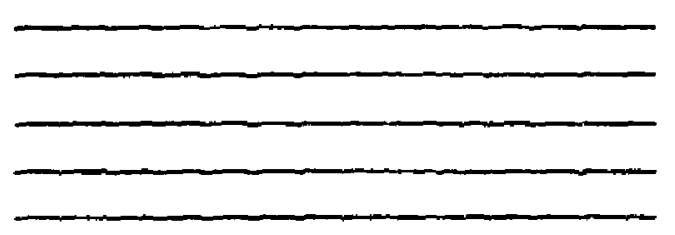


4.5.2 Actions (Circle appropriate letters) a. Compulsive. b. Frightened. c. Confident. d. Methodical, e. Disorganized. f. Followed plans. g. Deviated from plans. $h$. Encountered unexpected situations. i. Aware of witnesses, j. Careful to remove evidence. $k$. Not concerned with evidence. 1. In collusion with others. m. No collusion. n. Required cooperation of innocent people. $O$. No cooperation of others required. p. Actions were against a system. q, Actions were against people. $r$. Posed or disguised as somebody else. $s$. Acted under his own identity. $t$. Fearful of detection. u. Not fearful of detection. v. Successful. w, Partially successful. $x$. Not successful.

4.5.3 Collusion in the acts (Place an asterisk before name of the leader if not the suspect)

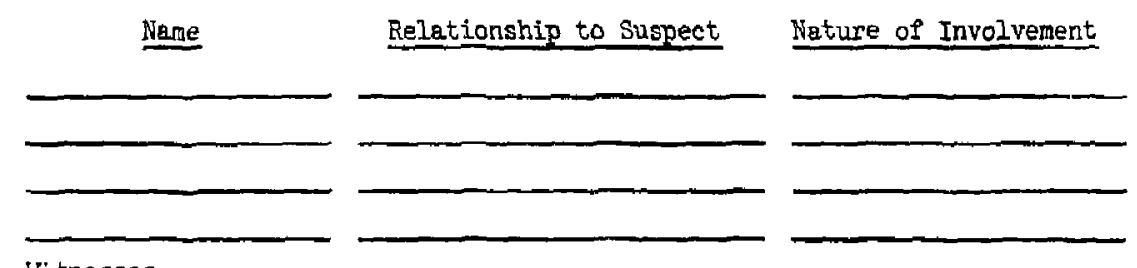

4.5.4 Witnesses

$\underline{\text { Name }}$ Relationship to Suspect Nature of Invclvement

4.5.5 Suspect disguised or posed as

4.5.6 Mistakes and deviation from plens

\subsubsection{Reasons for sucess or failure}

\subsection{After the acts}

4.6.1 (C1rcle appropriate letters) a. Eager to discuss his actions, b. Willing to discuss his actions. c. Unwilling to supply information. d. Left the scene of his actions normally. e. Left the scene in haste or abnormally. 
4.4.6 Flaning. (Circle appropriate letters) a. Acts were not planned. b. Acts were partially planned. c. Acts were completely planned. d. Plaming was a full time effort. e. Planning was 3 part time effort. f. Cost of the acts was estimated. g. Risk was evaluated. $h$. Sanctions if caught were known, i. Avoidance of discovery was planned. j. Discovery was expected after the acts were perpetrated. $k$. If caught, exposure to family, friends or associates was feared. 1 . If caught, public exposure was feared. m. Certain of carrying out plans. n. Uncertain of carrying out plans. o. Would be successful even though caught or exposed. $p$. Would not be successful if caught or exposed, q. Confident of success. r. Not confident of success. $s$. Was not aware of criminal nature of the acts. $t$. Was not aware of unethical, unfair or inmoral nature of the acts. u. A shange in protection of the system could have aborted plans. v. New knowledge required, $w$, New knowledge not required. $x$. New skills requirea. y. New skills not required. z. Planning included other participants. * Act planned from a position of trust.

4.4.7 New skills acquired

\subsubsection{New knowledge acquired}

4.4.9 Collusion (Place an asterisk before name of the planning leader if not the suspect)

Name Relationship to Suspect Nature of Involvement

4.4.10 Date act was first conceived

By whom

4. 4. 11 Planning period. From to

\subsection{During the acts}

4.5.1 Perind of time to conduct the acts (date, time). From to 
f. Sees himself as a hero, g. Is remorseful. h, Is self-righteous.

i. Is indifferent. $\mathrm{j}$. Is elated. $k$. Shows snimosity toward victims.

1. Shows animosity toward other involved parties. m. Believes his actions were eppropriate for the circumstances. $n$. Feels he was wrong in his actions. 0 . Would repeat the actions under slmilar sircumstances. p. Would never repeat his actions. q. Willing to make restitution. $r$. Not willing to make restitution. $s$. Feels he made a net gain towards his objectives. t. Suffered a net loss towards his objectives. 4.6.2 What did the suspect fear most (Rank by numbers or leave blank if not applicable)
a. - Discovery of the act
b. ___ Exposure of him as the perpetrator
c. Harm to others
d. _- Punishrent
e. Publicity
f. Other
g. Other

4.6.3 Feelings towards other involved parties

Nane

\section{Feelings}

4.6.4 What circumstances would have stopped the suspect's actions?

4.6.5 Alternative actions suspect could have taken:

Action

Reason for Rejection 
Appendix E

PROJECT PROGRESS REPORT

December 20, 1972 
Progress Report 1

Covering the Period 19 September through 31 December 1972

Stanford Research Institute Project 2194

\title{
TECHNICAL SERVICES
}

by

Donn B. Parker

Contract $P / A$ No. 91 Under AT(04-3)-115

\author{
Prepared for \\ U.S. Atomic Enerby Commission \\ University of California \\ Lawrence Livermore Laboratory \\ P.O. Box $80 B$ \\ Livermore, California 94550 \\ Atta: Ivan Morvay L379
}

Copy No. 
The purpose of the work performed is to provide the results of an investigation of computer installations and computer manufacturers to identify those installations in which information has been compromised by unauthorized persons.

\section{TECHNICAL FROGRESS}

The first dreft of a questionnaire to be used by an investigator of incidents of intentional, unauthorized access to multiaccess computer systems was completed on October 2, 1972, It was based on a questionnaire developed previous to this project and one designed by Judy Ford of the RISOS Project. The questionnaire was reviewed for technical accuracy, completeness, and applicablility by Dr. Peter Neumann and Mr. Carrol Kerns, SRI Information Sciences Dirlsion and by Dr. Brian Parker, a forensic scientist. Critiques were recelved in the form of annotated copies of the questionnaire. The RISOS project personnel reviewed the document in detail.

The first draft proved to be too long, too wide in scope covering items not of perticular interest to RISOS, and there was not enough depth of items concerning technical aspects of the operating systems and hardware constituting the objects of attack.

The second draft, satisfying the critiques of the first draft, was sent to RISOS on November 29, 1972. Mr. Steven Oura, a sociologist at SRI, reviewed the suspect section of the questionnaire. The final draft will include his suggestions. Otherwise, only minor problems were identified by the RISOS staff.

The draft questionnaire was used to document the ISD vs UCC Program Theft case from documents collected and investigations made before this project started. This test revealed a number of shortcomings in the practical areas of sufficlent space for answers, anbiguous and unclear wording of questions, and depth of details.

The second draft questionneire was also used in a new investigation of the Cincinnati/Louisville Time-Sharing Use Fraud case that occurred in 1970. This test also resulted in new insights into the questionnaire content and format.

The Cincinnati/Louisville case investigation resulted in refining some techniques in field investigation that will be used in developing a manual on this subject. This was an appropriate case because it involved travel to an unfamiliar site, unfamiliar computer system environment, and a relatively sophisticated method of uneuthorized access and attack on the operating system of a multiaccess service.

I have also assisted Doug Webb of RISOS in his investigation of EDP audit techniques. I supplind him with documents, information from my field research in EDP audit, and sources of information. 


\section{TRIPS, MEETINGS AND PRESENTATIONS}

Meetings were held with the RISOS Praject staff on October 3, November 7 and Decerber $?$ in 1972. The first was a presentation describing uy previous research activities and results. The other two meetings were held to review the questionnaire drafts and exchange intelligence information about activities in computer security research. The RISOS staff gave me assistance concerning computer penetration incidents and contacts among computer manufacturers.

I attended the NBS/ACM Workshop on Controlled Access on December 11-13 in Rencho Senta Fe. I chaired an ACM SIGCOSIM session at the FJCC in Anaheim on December 4 at which Bob Abbott served as a panelist. Two meetings were arranged with Jerry Schneider, convicted of perpetrating a computer-related theft, One meeting was attended by Shig Tokubo, the other by Bob Abbott. A report on the first meeting with Schneider was prepared and submitted to Bob Abbott.

Unauthorized use of computing services was investigated at the Stanford University Computation Center on November 28 and at Metridata lime-Sharing Service in Loulsville, Kentucky, on December 14. A trip was made from Loulsville to Minneapolis where a day was spent telking with people concerned with security at Control Data and Univac. Reports of these meetings and investigation results are being written. 
APPENDIX $F$

THIRTY-EIGHT CASE HISTORI ES 


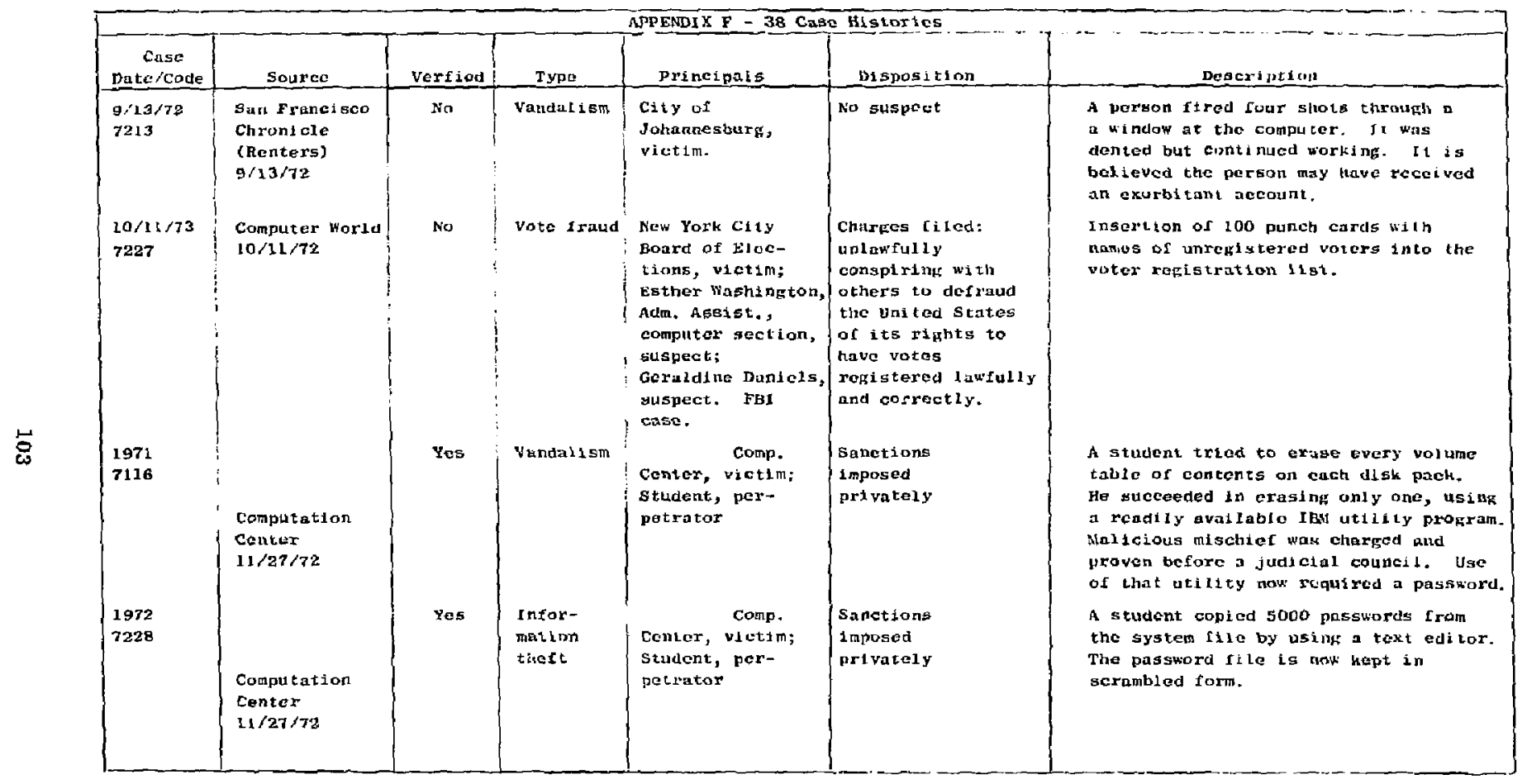




\begin{tabular}{|c|c|c|c|c|c|c|}
\hline $\begin{array}{c}\text { Case } \\
\text { Datefcode }\end{array}$ & Source & verfied & Type & Principals & Disposition & Description \\
\hline $\begin{array}{l}1972 \\
7244\end{array}$ & $\begin{array}{l}\text { Computation } \\
\text { Center }\end{array}$ & Yes & Time thef $\mathrm{t}$ & $\begin{array}{l}\text { Computa- } \\
\text { twon center, vic- } \\
\text { tm; Student, per- } \\
\text { pelrator }\end{array}$ & $\begin{array}{l}\text { Senctions } \\
\text { inposedd } \\
\text { privately }\end{array}$ & 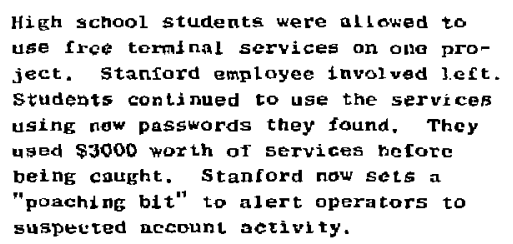 \\
\hline $\begin{array}{l}9 / 27 / 72 \\
7295\end{array}$ & $\begin{array}{l}\text { Computez Forld } \\
9 / 27 / 72\end{array}$ & No & $\begin{array}{l}\text { Che ch } \\
\text { forgery }\end{array}$ & $\begin{array}{l}\text { Anonymous bank, } \\
\text { gorvice bureau, } \\
\text { victidi }\end{array}$ & $\begin{array}{l}\text { No record of } \\
\text { results }\end{array}$ & $\begin{array}{l}\text { Check passer made photostat copfes of } \\
\text { a peyrall cheek with payee and date } \\
\text { changed. The MICR code falied to be } \\
\text { read becuse the code did not use } \\
\text { magnetic inh. The service burcan re- } \\
\text { placed the check whth a correct substi- } \\
\text { tute and let it pass because the bank } \\
\text { had accopted the check. }\end{array}$ \\
\hline $\begin{array}{l}11 / 15 / 72 \\
7214\end{array}$ & $\begin{array}{l}\text { Ms. Terry Davis, } \\
\text { Ameritan } 5 \text { tan-, } \\
\text { dard, 4O w. 40tr } \\
\text { St., New York } \\
10018\end{array}$ & No & Viandalism & $\begin{array}{l}\text { victims. } \\
\text { Employee of a } \\
\text { Berkeley or } \\
\text { San Franciseo } \\
\text { messenger service, } \\
\text { perpetrator }\end{array}$ & $\begin{array}{l}\text { No record of } \\
\text { resul ts }\end{array}$ & 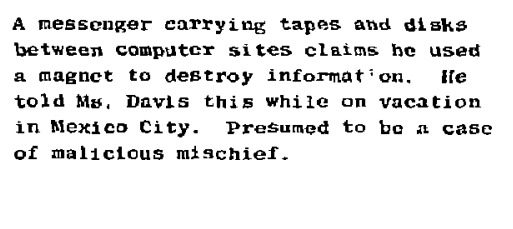 \\
\hline $\begin{array}{l}9 / 27 / 72 \\
7229\end{array}$ & $\begin{array}{l}\text { Computer World } \\
9 / 27 / 72 \\
\text { Michael Sorkin }\end{array}$ & No & $\begin{array}{l}\text { Invasion } \\
\text { of pri- } \\
\text { vacy }\end{array}$ & $\begin{array}{l}\text { Lown State Com- } \\
\text { misstoner of } \\
\text { Pubric Safety } \\
\text { Michael Sollers, } \\
\text { dofendent. } \\
\text { Freeland Halker } \\
\text { plaintiff. Iowa } \\
\text { Civil Liborties } \\
\text { Undon. }\end{array}$ & Charges filed & $\begin{array}{l}\text { Plaintiff clatms criminal file on hym } \\
\text { was sent to the fBI clatming he is a } \\
\text { known criminal, whereas al though he had } \\
\text { seven arrestg, he had no convictions. }\end{array}$ \\
\hline
\end{tabular}




\begin{tabular}{|c|c|c|c|c|c|c|}
\hline & & & & APPENDIX $F$ (cont & & \\
\hline Date/Code & Source & Verified & Type & pringipals & D1sposition & Description \\
\hline $\begin{array}{l}10 / 11 / 72 \\
6923\end{array}$ & $10 / 1) / 72$ & No & Theft & $\begin{array}{l}\text { MIT, v\&ctim; } \\
\text { MIT campus } \\
\text { PatrnI }\end{array}$ & Conviction & $\begin{array}{l}\text { A student stole a PDPB compulex from } \\
\text { MIT, Eoston. }\end{array}$ \\
\hline $1 / 5 / 72$ & $\begin{array}{l}\text { Digital Equip- } \\
\text { ment } \\
2 / 5 / 72 \\
\text { (sec Boston trip } \\
\text { notes) }\end{array}$ & Yes & Theft & $\begin{array}{l}\text { Digltal Equipment } \\
\text { corp, V Victim; } \\
\text { employee, thich. }\end{array}$ & Private senctions & $\begin{array}{l}\text { An empioyec ramaved a pDPB computer } \\
\text { from the manufacturing plant a piece } \\
\text { at a time and assembled it at home. } \\
\text { He was rired. }\end{array}$ \\
\hline $\begin{array}{l}8 / 14 / 72 \\
7236\end{array}$ & $\begin{array}{l}\text { Keith } \\
\text { Matcclivius, } \\
\text { ISD, OnkIand }\end{array}$ & wa & Frand & $\begin{array}{l}\text { Oakland, victim; } \\
\text { of Data prond } \\
\text { Divistor }\end{array}$ & & Employee fraud. \\
\hline $\begin{array}{l}1970 \\
7045\end{array}$ & $\begin{array}{l}\text { Robort Wright } \\
\text { Metridata, } \\
\text { Loulsvilie, Yy. } \\
\text { 12/14/72 } \\
\text { Charlos Mc } \\
\text { Guiness, } \\
\text { GET.S., } \\
\text { Bethesila, ma, }\end{array}$ & Yos & $\begin{array}{l}\text { Theft of } \\
\text { services }\end{array}$ & $\begin{array}{l}\text { Fla, , victim; two } \\
\text { engineers in } \\
\text { Detrolt, perpetra- } \\
\text { Lorb. }\end{array}$ & $\begin{array}{l}\text { No action } \\
\text { except ter- } \\
\text { mination of } \\
\text { services }\end{array}$ & 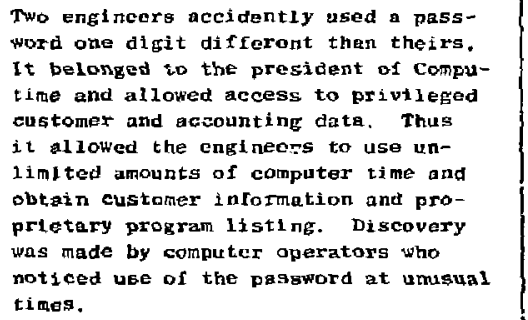 \\
\hline $\begin{array}{l}1972 \\
7214\end{array}$ & $\begin{array}{l}\text { Protected } \\
\text { source }\end{array}$ & Yes & $\begin{array}{l}\text { Tieft or } \\
\text { services }\end{array}$ & $\begin{array}{l}\text { Prolected vic- } \\
\text { tiaj; perpetratur }\end{array}$ & $\begin{array}{l}\text { Restituti on } \\
\text { made. }\end{array}$ & 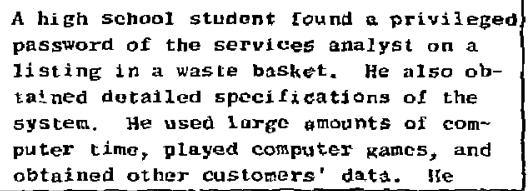 \\
\hline
\end{tabular}




\begin{tabular}{|c|c|c|c|c|c|c|}
\hline \multicolumn{7}{|c|}{ APPENDIX F (cont1 nued) } \\
\hline $\begin{array}{c}\text { Cuse } \\
\text { Dotacoude }\end{array}$ & Sturec & Yorified & Type & Prineipals & Disposition & Description \\
\hline & & & & & & $\begin{array}{l}\text { was discovered when a computer operator } \\
\text { noticed seratch tapes being read beforc } \\
\text { belng written. }\end{array}$ \\
\hline$? 237$ & $\begin{array}{l}\text { Les Giey, } \\
\text { SNI } \\
12 / 26 \times 2\end{array}$ & $\mathrm{v}=\mathrm{s}$ & $\begin{array}{l}\text { Embezzie- } \\
\text { ment }\end{array}$ & $\begin{array}{l}\text { Painting contractor, } \\
\text { Victim; controller, } \\
\text { perpetrator }\end{array}$ & $\begin{array}{l}\text { Controlker was } \\
\text { fired }\end{array}$ & $\begin{array}{l}\text { Controller eabezzled by setting up } \\
\text { dunmy vendors iu accounts payable. } \\
\text { Actions were discoverod when Grey, } \\
\text { as a burreughs anatyst, convorted to a } \\
\text { now systern. }\end{array}$ \\
\hline $\begin{array}{l}1972 \\
7215\end{array}$ & $\begin{array}{l}\text { Mervin Miller. } \\
\text { Wortal Bank, } \\
\text { Dr. }\end{array}$ & Yes & Vandal is sill & $\begin{array}{l}\text { University, victin; } \\
\text { student, perpetrator }\end{array}$ & & $\begin{array}{l}\text { A student gaingd priviliged access to } \\
\text { the t1me-sharing system and caused } \\
\text { frequent crashes. Malictous mischief. }\end{array}$ \\
\hline & $\begin{array}{l}\text { Universily } \\
\text { Computer } \\
\text { Conter }\end{array}$ & & & & & \\
\hline $\begin{array}{l}1967 \\
6741\end{array}$ & $\begin{array}{l}\text { Datamation } \\
12 / 67, \text { p. } 78\end{array}$ & xo & $\begin{array}{l}\text { Unathior- } \\
\text { ized use } \\
\text { of equip- } \\
\text { ment }\end{array}$ & $\begin{array}{l}\text { Chi cago Board of } \\
\text { Education, victimi } \\
\text { five employoes, } \\
\text { including direc- } \\
\text { tor of the bureau } \\
\text { James A. Quinn, } \\
\text { suspects. }\end{array}$ & Investigation & $\begin{array}{l}\text { Five employees operated their orn data } \\
\text { processing firm using an input scanner } \\
\text { of their cmployer's. All resigned. }\end{array}$ \\
\hline $\begin{array}{l}1972 \\
7341\end{array}$ & Computer World & No & $\begin{array}{l}\text { Sedition } \\
\text { and } \\
\text { hostility } \\
\text { to the } \\
\text { state }\end{array}$ & $\begin{array}{l}\text { Zagreb, Yugosiavia } \\
\text { : University data } \\
\text { processing center, } \\
\text { victim; five students } \\
\text { sispeets. }\end{array}$ & Arrested & $\begin{array}{l}\text { Five students replaced busiress output } \\
\text { data with antigoversment slogans. }\end{array}$ \\
\hline $\begin{array}{l}1973 \\
7341\end{array}$ & $\begin{array}{l}\text { Computer world } \\
1 / 24 / 73\end{array}$ & so & Fraud & $\begin{array}{l}100 \text { Mi chigan insurance } \\
\text { pollicy holders, vic- } \\
\text { tims; agent for United } \\
\text { presidential Li fo Ins. } \\
\text { Co., suspect. Robert } \\
\text { Rowo, David Feintucb, } \\
\text { Mich, Commerce Dept., } \\
\text { Ins. mureau, prosecu- } \\
\text { tors }\end{array}$ & Inyestigation & $\begin{array}{l}\text { Agent used computer analysis of } 1 \text { ife } \\
\text { insurance to confuse policyhol ters } \\
\text { saying the computer recommended his } \\
\text { policy over theirs. }\end{array}$ \\
\hline
\end{tabular}




\begin{tabular}{|c|c|c|c|c|c|c|}
\hline \multicolumn{7}{|c|}{ APPENDIX $\mathrm{F}$ (continued) } \\
\hline $\begin{array}{c}\text { Cisse } \\
\text { pata 'Code }\end{array}$ & Source & Vorifigd & Tуре & Princtpals & Disposition & Description \\
\hline $\begin{array}{l}1972 \\
7838\end{array}$ & $\begin{array}{l}\text { Landon Times } \\
5 / \jmath_{1} / 72 \\
\text { D. J, Eenzi mwa } \\
1 / 26 / 73\end{array}$ & No & $\begin{array}{l}\text { Ember.zle- } \\
\text { ment } \\
c 3,000\end{array}$ & $\begin{array}{l}\text { Westminster Dank, } \\
\text { vietim, Scveral } \\
\text { staff, perpelrators. }\end{array}$ & Convicted & 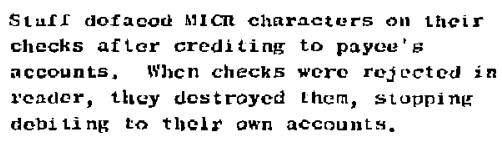 \\
\hline $\begin{array}{l}1972 \\
79210\end{array}$ & $\begin{array}{l}\text { Data Banks } \\
\text { in a Free } \\
\text { Socicty, } \\
\text { w"estin Baker, } \\
\text { Quadrankie. } \\
\text { p. } 139\end{array}$ & No & Friand & $\begin{array}{l}\text { TRW Credit Dala, } \\
\text { viotim; former } \\
\text { cmployoo, pex- } \\
\text { petrator }\end{array}$ & Not Eound & $\begin{array}{l}\text { A former employee abtatned credit } \\
\text { reports by using the idenctricution } \\
\text { number of a logitimate subseriber. } \\
\text { The number was ehanged. }\end{array}$ \\
\hline $\begin{array}{l}1972 \\
72211\end{array}$ & $\begin{array}{l}\text { Dala Eanks } \\
\text { in a Free } \\
\text { Socioty, } \\
\text { Weatin Buker, } \\
\text { Quadrangle. } \\
\text { p. } 139\end{array}$ & No & Fraud & $\begin{array}{l}\text { ThW Credil Data, } \\
\text { victimi enplayce, } \\
\text { perpotratol. }\end{array}$ & Fired & 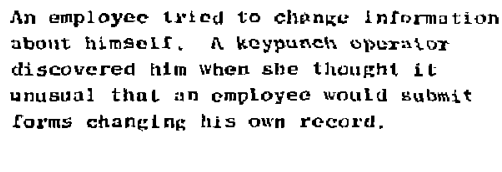 \\
\hline $\begin{array}{l}2972 \\
7239\end{array}$ & $\begin{array}{l}\text { California } \\
\text { state } \\
\text { liel rare Dept. } \\
\text { L1/27/72 }\end{array}$ & No & Fraud & $\begin{array}{l}\text { L.A. County } \\
\text { Social wol lare, } \\
\text { vict im }\end{array}$ & & $\begin{array}{l}\text { Wolfare grunts are paid from vouchers } \\
\text { and punch cards. An employee put } \\
\text { cxira cards tn computer ta produce } \\
\text { unauthorized frants. No suspects } \\
\text { tdentified. }\end{array}$ \\
\hline $\begin{array}{l}1973 \\
7311\end{array}$ & $\begin{array}{l}\text { Bob Hargraves, } \\
\text { Distmouth } \\
3 / 5 / 73\end{array}$ & Yos & Vandal 1 sa & $\begin{array}{l}\text { Dartinguth } \\
\text { Kiswit } \\
\text { Computer conter, } \\
\text { victimi student } \\
\text { at nates coltege, } \\
\text { perpetrator }\end{array}$ & $\begin{array}{l}\text { So nceioit } \\
\text { taken }\end{array}$ & 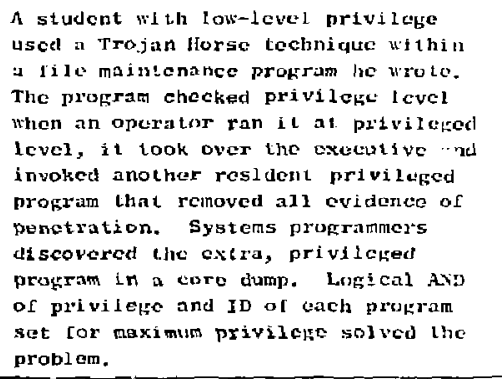 \\
\hline
\end{tabular}




\begin{tabular}{|c|c|c|c|c|c|c|}
\hline \multicolumn{7}{|c|}{ APPENDIX F (contl nued) } \\
\hline $\begin{array}{c}\text { Case } \\
\text { Datu/gode }\end{array}$ & Source & yerified & Type & PIIneipals & Dispasition & Description. \\
\hline $\begin{array}{l}1973 \\
7312\end{array}$ & $\begin{array}{l}\text { Charıes Rosen, } \\
\text { SRI }, 2 / 6 / 73\end{array}$ & Yes & Vanda l i som & vietim; $c$ ca. & & $\begin{array}{l}\text { Employaes returning rrom a strike } \\
\text { saboutufed the on-line parts inventory } \\
\text { and ordering system. }\end{array}$ \\
\hline $\begin{array}{l}1872 \\
72212\end{array}$ & $2 / 9 / 73$ & Yes & $\begin{array}{l}\text { Theft of } \\
\text { programs }\end{array}$ & $\begin{array}{l}\text { Sortware Leas } \pm \text { ng } \\
\text { Corp., James } \\
\text { Crrigle, suspect }\end{array}$ & & $\begin{array}{l}\text { A blind man and James Craigie con- } \\
\text { vinced programers to take sof tware } \\
\text { from their employers and sell it to } \\
\text { Sof tware Leasing which then markets } \\
\text { the sof tware. }\end{array}$ \\
\hline $\begin{array}{l}1972 \\
72213\end{array}$ & & Yes & $\begin{array}{l}\text { Thert of } \\
\text { programs }\end{array}$ & $\begin{array}{l}\text { Mejonnell Dougins } \\
\text { victim }\end{array}$ & $\begin{array}{l}\text { One employec } \\
\text { I1 red; onc dicd } \\
\text { of a heart } \\
\text { attack }\end{array}$ & $\begin{array}{l}\text { Two omployees took program listings } \\
\text { describing secret processes to be } \\
\text { patented. Both employees were scheduled } \\
\text { for layorf. }\end{array}$ \\
\hline $\begin{array}{l}1972 \\
72214\end{array}$ & $2 / 9 / 73$ & Yes & $\begin{array}{l}\text { Theft of } \\
\text { dossiers } \\
\text { Eor suld }\end{array}$ & London, vf etim & & $\begin{array}{l}\text { An omployee was selling dossiers } \\
\text { for } 65 \text { on the London black market. He } \\
\text { obtained them from an on-line Bs7oo } \\
\text { data bank. He was caught by a program } \\
\text { chango that trapped on a preassigned } \\
\text { namb th the file. }\end{array}$ \\
\hline $\begin{array}{l}1971 \\
71310\end{array}$ & $\begin{array}{l}\text { Reiner von sur } \\
\text { Muthlen, } \\
\text { W1rtschaft und } \\
\text { Politik } \\
\text { 10/10/71, } \\
\text { ingurer }\end{array}$ & No & $\begin{array}{l}\text { Payroti } \\
\text { theft } \\
380,000 \mathrm{pM}\end{array}$ & $\begin{array}{l}\text { Industrial Co. } \\
\text { in Solingen, } \\
\text { Ger., victim }\end{array}$ & $\begin{array}{l}\text { Empl oyee was } \\
\text { forced to malso } \\
\text { restitution }\end{array}$ & $\begin{array}{l}\text { An emplayee changed purch card input } \\
\text { to change emplayee salaries soon after } \\
\text { conversion to the computer. Management } \\
\text { not } 1 \text { cod the high salaries and a surpriso } \\
\text { audit resulted th apprehension }\end{array}$ \\
\hline $\begin{array}{l}1971 \\
72311\end{array}$ & $\begin{array}{l}\text { Feiner von sur } \\
\text { Muhlen, } \\
\text { Wirtschaft und } \\
\text { Politik } \\
\text { bo/20/71, } \\
\text { computer manu- } \\
\text { facturer }\end{array}$ & no & $\begin{array}{l}\text { Pension } \\
\text { theft }\end{array}$ & $\begin{array}{l}\text { West German } \\
\text { chersical ifim, } \\
\text { victim }\end{array}$ & & $\begin{array}{l}\text { An employee in top altered deceased } \\
\text { erployea's ds ta to have the deceased's } \\
\text { pension patd into hy own bank account. }\end{array}$ \\
\hline
\end{tabular}




\begin{tabular}{|c|c|c|c|c|c|c|}
\hline & & & & APPENDIX F con & & \\
\hline $\begin{array}{c}\text { Cuse } \\
\text { Duta/Code }\end{array}$ & Sourco & verified & Iype & Principals & ElBpositian & Description \\
\hline $\begin{array}{l}1971 \\
71312\end{array}$ & $\begin{array}{l}\text { Heiner von } \\
\text { sur mumlen, } \\
\text { wirtschart } \\
\text { und Politik } \\
\text { to/lofil } \\
\text { computex } \\
\text { manufacturer }\end{array}$ & $\therefore$ & $\begin{array}{l}\text { Ponsian } \\
\text { theft }\end{array}$ & $\begin{array}{l}\text { Canadian Ins. } \\
\text { Co., victim }\end{array}$ & Apprehended & $\begin{array}{l}\text { An exployee changed several deceased } \\
\text { insured persong' account numbers to his } \\
\text { own to collect the1r pensions. He } \\
\text { was caught when a staple in a punch } \\
\text { card fored manual handing which } \\
\text { revealed several cards with the sume } \\
\text { iumber. }\end{array}$ \\
\hline $\begin{array}{l}1971 \\
71313\end{array}$ & $\begin{array}{l}\text { Roinor von } \\
\text { sur Mluhlen, } \\
\text { wirtschaft } \\
\text { und polltik, } \\
\text { 10/10/71, } \\
\text { computer } \\
\text { manufacturer }\end{array}$ & Nor & $\begin{array}{l}\text { Ponsion } \\
\text { Thert }\end{array}$ & & Apprehendod & 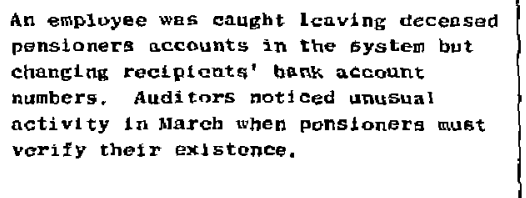 \\
\hline $\begin{array}{l}1971 \\
71314\end{array}$ & $\begin{array}{l}\text { Rel ner von } \\
\text { Sur Muhlen, } \\
\text { wirtsehaft } \\
\text { und Politik, } \\
\text { io/10/71 } \\
\text { computer } \\
\text { manufacturer }\end{array}$ & No & $\begin{array}{l}\text { Payrali } \\
\text { theft }\end{array}$ & $\begin{array}{l}\text { U.S. rime, } \\
\text { vectim }\end{array}$ & Apprehended & $\begin{array}{l}\text { EDP oporator pressud the "repeat" } \\
\text { on the printer to print } 200 \text { extran copies } \\
\text { of his check. He was caught when ho } \\
\text { cashed } 37 \text { checks all at the same bank. }\end{array}$ \\
\hline $\begin{array}{l}1971 \\
71315\end{array}$ & 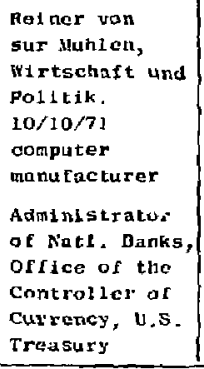 & no & $\begin{array}{l}\text { Embezzile- } \\
\text { mant } \\
\$ 6.8 \\
\text { mil11ion }\end{array}$ & $\begin{array}{l}\text { v.s. Hank, } \\
\text { vect int }\end{array}$ & Apprehonded & 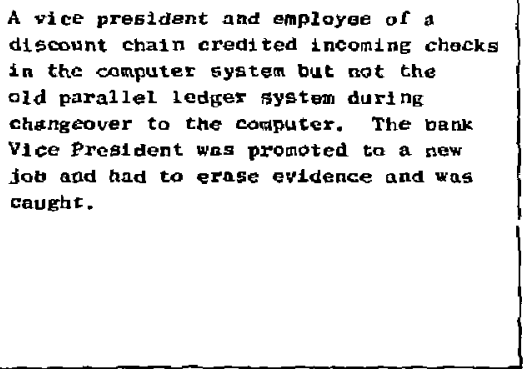 \\
\hline
\end{tabular}




\begin{tabular}{|c|c|c|c|c|c|c|}
\hline \multicolumn{7}{|c|}{ APPENDI $X$ F (conti nued) } \\
\hline $\begin{array}{c}\text { Case } \\
\text { Dataj/Cade }\end{array}$ & Source & verifiad & Tyme & Fxineipsis & Disposition & Deseription \\
\hline $\begin{array}{l}1971 \\
71316\end{array}$ & $\begin{array}{l}\text { Roiner von } \\
\text { gar Muhlen, } \\
\text { Wirtschaft und } \\
\text { Politik, } \\
10 / 10 / 71 \\
\text { computer } \\
\text { manufacturer } \\
\text { British Assac. } \\
\text { for resociali- } \\
\text { zation or ex- } \\
\text { convicts }\end{array}$ & No & $\begin{array}{l}\text { Embezalo- } \\
\text { ment } \\
\$ 17,000\end{array}$ & $\begin{array}{l}\text { British, }\{i r m, \\
\text { victim }\end{array}$ & $\begin{array}{l}\text { Convicted. } \\
\text { served } 2 \text { years } \\
\text { in prison }\end{array}$ & $\begin{array}{l}\text { Progranmor transferred } 217,000 \text { to a } \\
\text { speclal error wrtto-off account. }\end{array}$ \\
\hline $\begin{array}{l}1971 \\
71317\end{array}$ & $\begin{array}{l}\text { Reiner von } \\
\text { sus Munlen, } \\
\text { Wirtschatt } \\
\text { und Poltitik, } \\
\text { 10/10/7t }\end{array}$ & No & $\begin{array}{l}\text { Embezzic- } \\
\text { ment }\end{array}$ & $\begin{array}{l}\text { A bank, } \\
\text { victitim }\end{array}$ & & $\begin{array}{l}\text { An accounting prakradger changed a } \\
11 \text { mit chock for } \$ 2000 \text { to } \$ 200,000 \text { to } \\
\text { claim a higher amount of cradit than } \\
\text { was al lowed. }\end{array}$ \\
\hline $\begin{array}{l}1971 \\
71318\end{array}$ & $\begin{array}{l}\text { Re1 ner von } \\
\text { sur Muhien, } \\
\text { wirtschaft } \\
\text { und Politik, } \\
10 / 10 / 71 \\
\text { CPA Assigtant } \\
\text { who traced } \\
\text { the mani- } \\
\text { pulator }\end{array}$ & No & $\begin{array}{l}\text { Embex,zle- } \\
\text { ment } \\
480, \text { uoord }\end{array}$ & $\begin{array}{l}\text { Hamburg bank, } \\
\text { v1etim }\end{array}$ & & A progranmer collected round-downs. \\
\hline $\begin{array}{l}1971 \\
72215\end{array}$ & $\begin{array}{l}\text { nelner voll } \\
\text { sur Muhlen, } \\
\text { wirtsohaft } \\
\text { und Polittl, } \\
10 / I 0 / 71 \\
\text { CPA - aistant } \\
\text { who tracerd } \\
\text { the mani- } \\
\text { pulator }\end{array}$ & so & Data theft & $\begin{array}{l}\text { U.S. econo- } \\
\text { mic data } \\
\text { collection } \\
\text { firm, victim }\end{array}$ & $\begin{array}{l}\text { Employees } \\
\text { fí rod }\end{array}$ & $\begin{array}{l}\text { Two employees extracted and yold data. } \\
\text { After thoy were fired, they tried } \\
\text { to get others to do the same thing. }\end{array}$ \\
\hline
\end{tabular}




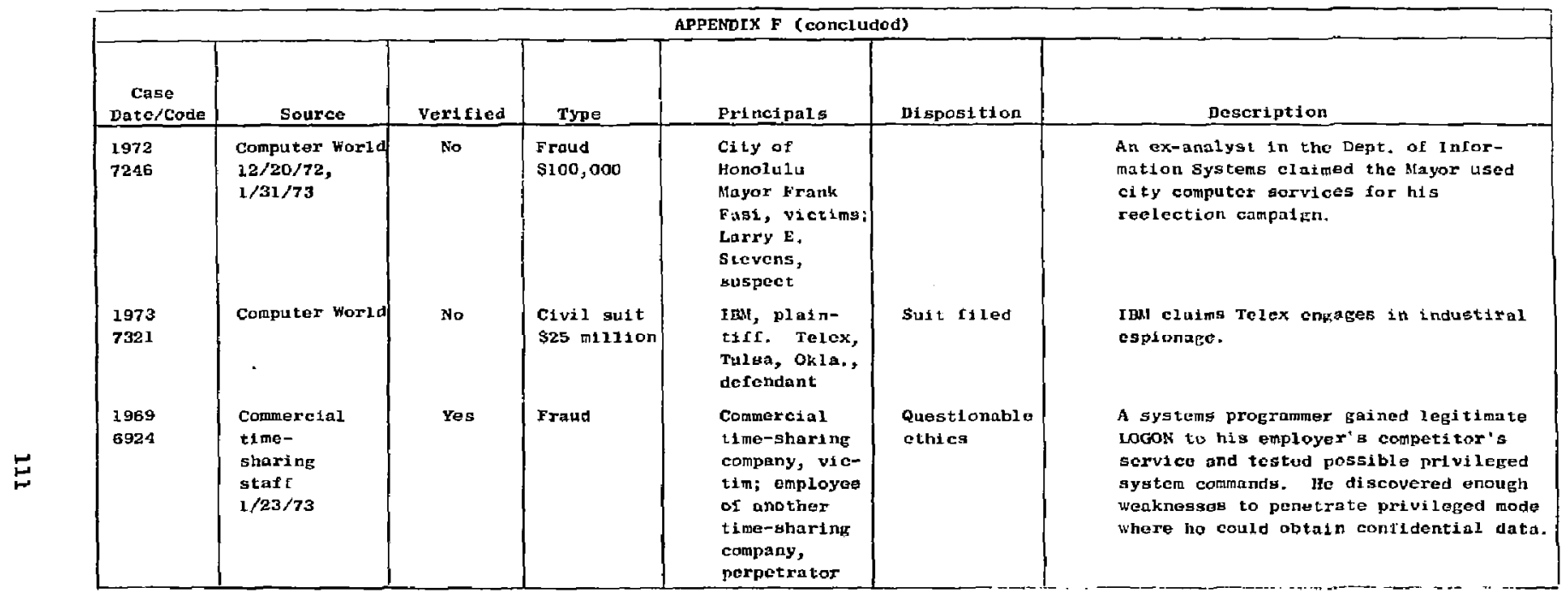


Appendix $G$

CASE HISTORIES INYOLVING MULTIACCESS COMPUTER SYSTEMS 


\section{Appendix G}

\section{CASE HISTORIES INYOLVING MULTIACCESS COMPUTER SYSTEMS}

\section{NOTE}

The purpose of this appendix is to assemble in one place references to cases involving unauthorized access to or other compromise of a timesharing system. A conmon feature of many of these cases is the subversion or penetration of operating system security. Many of the cases mentioned in this appendix are described in somewhat greater detail in Appendix F. 


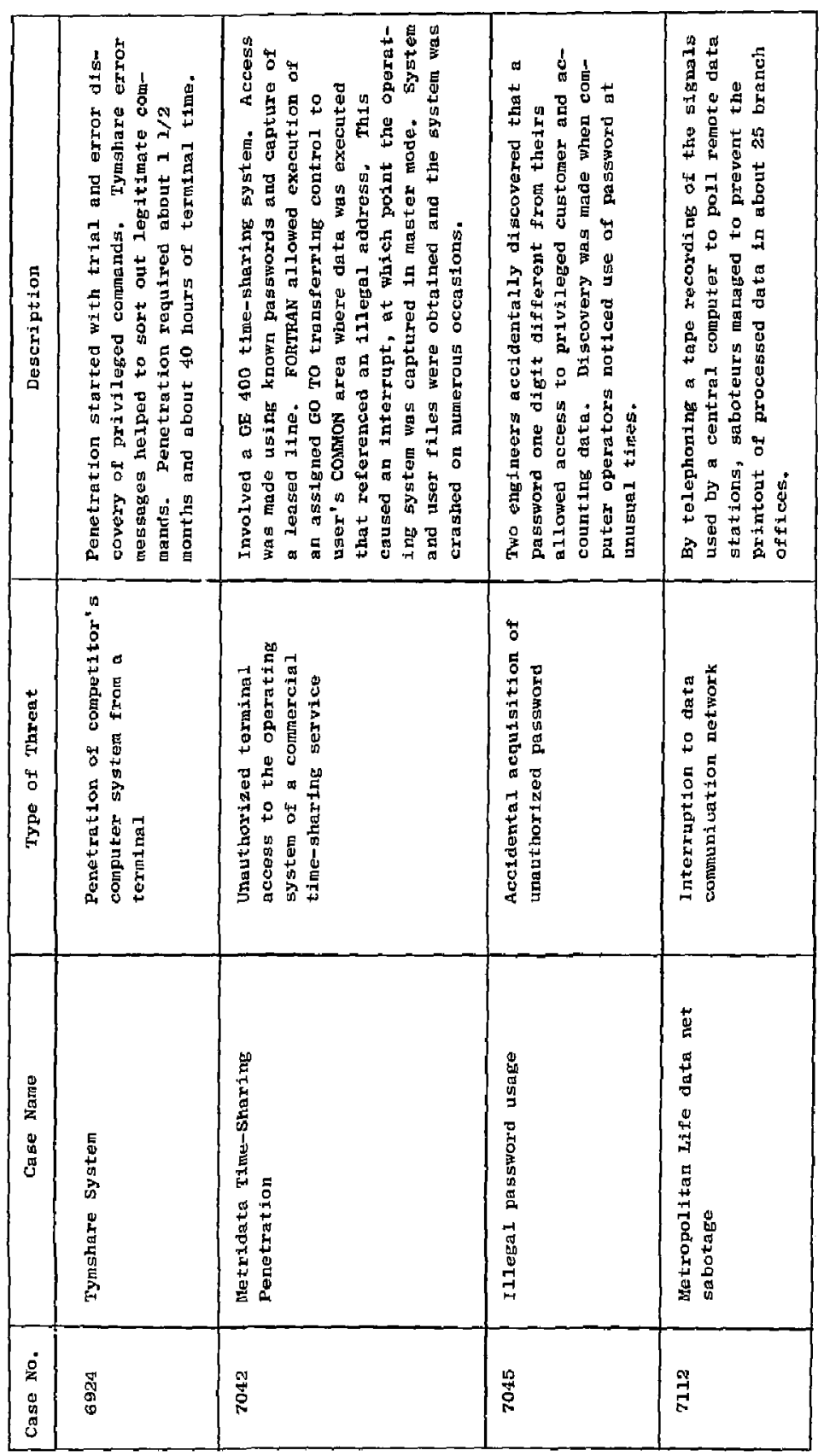




\begin{tabular}{|c|c|c|c|}
\hline Case No. & Case Name & Type of Threat & Description \\
\hline 7116 & Stanford time sharing vandaIlsm & $\begin{array}{l}\text { Attempted modipication of } \\
\text { operating systumil }\end{array}$ & $\begin{array}{l}\text { A student tried to erabe every vToc on oach disk } \\
\text { pack in the eystem. He succeeded in eraging } \\
\text { only one, using a readily available lgn utility } \\
\text { program. Use of that utility now requires a } \\
\text { password. }\end{array}$ \\
\hline 7121 & ISD va uCC Program Theft & $\begin{array}{l}\text { Theft of a program } \\
\text { listing }\end{array}$ & $\begin{array}{l}\text { An employee of vCc used a ucc remote job entry } \\
\text { term‡nal and public telephone cirsuits to steal } \\
\text { a listlng of a program stored in the ISD com- } \\
\text { puter and alleged to be a trade secret of ISD. }\end{array}$ \\
\hline 7228 & $\begin{array}{l}\text { Computer Sharing Services } \\
\text { (CSS) vs Computer Time Corp } \\
\text { (CTS) }\end{array}$ & Alleged sof tware theft & $\begin{array}{l}\text { Presently in littgation. Plaintiff (CSS) alleges } \\
\text { that three former employees appropriated prom } \\
\text { prietary software (used in a GE-400 system) for } \\
\text { the benefit of a competitor. }\end{array}$ \\
\hline 7221 & Schnetdex/PT\&T & $\begin{array}{l}\text { Theft of equipment } \\
\text { using computer-ardering } \\
\text { codes }\end{array}$ & 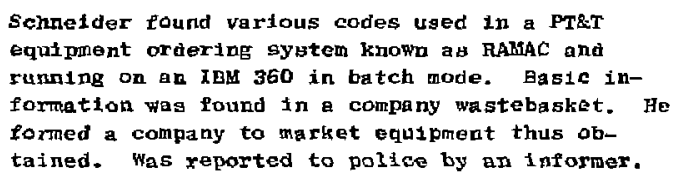 \\
\hline 7228 & $\begin{array}{l}\text { Unf versity Computation Center } \\
\text { November } 1972\end{array}$ & Password file theft & $\begin{array}{l}\text { A student copied } 5000 \text { passwords from the system } \\
\text { file by ustng a text editor. Password file is } \\
\text { now kept in scrambled form. }\end{array}$ \\
\hline 72210 & TRIS Credit data theeft & $\begin{array}{l}\text { Unauthortzed access to } \\
\text { a confidential file }\end{array}$ & $\begin{array}{l}\text { A Pormer employee obtained credit reports by } \\
\text { using the idontification password of a legitimate } \\
\text { subsertber to the servica. The number was } \\
\text { changed. }\end{array}$ \\
\hline
\end{tabular}




\begin{tabular}{|c|c|c|c|}
\hline Case No. & Case Name & Type of Threat & Description \\
\hline 72214 & Data theft from on-line system & Theft of confidiontial data & 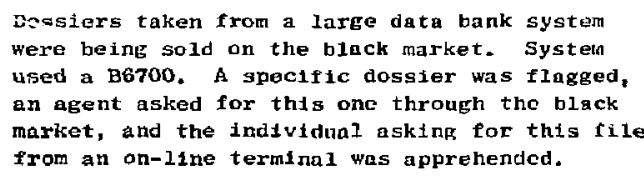 \\
\hline 7244 & $\begin{array}{l}\text { High school student's } \\
\text { unauthorized access to a } \\
\text { nat lonal tzizc-sharing } \\
\text { gervice }\end{array}$ & $\begin{array}{l}\text { Theft of timo on a large } \\
\text { system }\end{array}$ & $\begin{array}{l}\text { Student found terminal output listings in a } \\
\text { wastebasket. Had access te torminal through } \\
\text { high sehool computer education program. List- } \\
\text { ings included account numbers and passwords. } \\
\text { He proceded to use large amounts of compiter } \\
\text { t1me. Discovered by an operatcr who noticed } \\
\text { activity at unusual times. }\end{array}$ \\
\hline 7311 & $\begin{array}{l}\text { Dartmouth BAsic system Trojan } \\
\text { Horse penetration }\end{array}$ & $\begin{array}{l}\text { Entry gained into system } \\
\text { as a challenge }\end{array}$ & $\begin{array}{l}\text { A student's program cheiked privilege level, } \\
\text { It could take over exocutive and invoke another } \\
\text { privileged program that rcmoved all evidence } \\
\text { of penatration. The extra, privileged, progran } \\
\text { was discovered in a core dump. }\end{array}$ \\
\hline
\end{tabular}

